\title{
鋼の脱酸速度についで
}

\author{
川和 高 㯖**.大久保 益 太苂
}

\section{Kinetic Studies on Deoxidation of Steel}

\author{
Takaho KAWAWA and Masuta $\overline{\mathrm{O}}_{\mathrm{KUBO}}$
}

\section{Synopsis:}

Single- and complex-deoxidations with $\mathrm{Mn}, \mathrm{Si}$, and $\mathrm{Al}$ are practised in steel baths melted by highfrequency induction furnace and Tammann-oven, respectively. Deoxidation-process are analysed on the stand point of kinetics with an eye to quantitative measurement of the separation-rate of primary inclusion. The results of experiments and evaluation are summarized as follows:

(1) Deoxidation-process in transient time just after the addition of deoxidizers is different from that during the stationary time after the transient time.

(2) In transient time just after the addition of deoxidizers they are in course of reaction with oxygen in iron, and produced inclusions have the tendency to coagulate because of ( $\mathrm{FeO}$ ) or $(\mathrm{MnO}$ ) in the presence of $\mathrm{Mn}$, in inclusions as a component, whose rapid separation brings about deoxidation of steel.

(3) After the transient time deoxidation-product separates from bath in course of time according to the mathematical form $\mathrm{C}=\mathrm{Co} \exp (-k t)$ ( $t$ : time) in the stirred bath.

(4) As the separation-rate coefficients $k$ differ in different kinds of crucibles, rate-determing step of separation of primary inclusion in stirred bath is chemical reaction between crucible materials and deoxidation-products.

( 5 ) Contrary to stirred bath separation-rate of primary inclusion in tranquil steel bath is confirmed to follow the theoretical equation which is introduced for the first time, assuming the validity of Stokes' law.

(6) The above theoretical equation can well explain the separation-rate of inclusion in tranquil steel bath when the mathematical distribution form of inclusion radius, which follows $N=A \exp (-\mathrm{Ar})$ ( $\gamma$ : Radius of primary inclusion particles) and bath height are given.

(7) Separation of inclusion in tranquil steel bath as in ladle would be promoted by stirring the steel bath.

(Received 28 Aug. 1967)

\section{1. 緒言}

従来脱酸に関寸石研究の多くは平衡論的な研究々鋼中

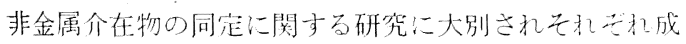
果を打さめてきた。しかし現場ては鋼中非金属介在物に よる鋼の久陌が常に問題乞なつている。このような現場

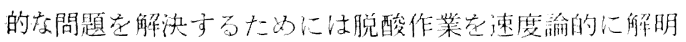
し, 特に 1 次介在物の浮上速度定量化し, 同時に浮上:

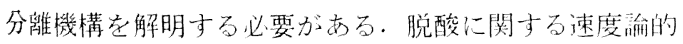
研究注数少なく, W. A. F ISCHER $5^{1)}$, 松下ら 2)の研究が 目につく程度である。そこで本研究では現場的に使用さ れている $\mathrm{Mn}, \mathrm{Si}, \mathrm{Al}$ による単独，および共同脱酸圭 速度渝的立場から解明し，特に1次脱酸生成物の浮上分 離速度を它量化し，合わせてその浮上分離機權を解明し ‡.

\section{2. 実 験 方 法}

現場の脱酸作業は炉内脱酸と取鍋脱酸上に大別され る. 炉内の鋼浴あるいは出鋼時の取鍋の鋼浴は，掜拌の 程度の差はあれ一種の貿拌浴である。一方出鋼後の取鍋 は一種の静止浴と見なすことができる。研究公的に得ら 机る鄮掉浴のモデルとして周波数 $30 \mathrm{KG}$ の高周波炉を 選んだ。次に静止浴のモデルとして大型タンマン炉在使

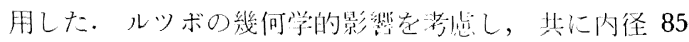
$\mathrm{mm} \phi$ のルツボを使用した。ルツボ材質は特にことわら ないかきり容易に市販品として得られる $\mathrm{MgO}$ を使用し

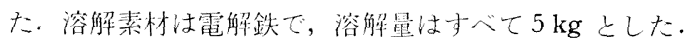

* 昭和 39 年 10 月本会誁演大会上り発表 昭和 42 年 8 月 28 日受付

** 日本鋼管 (株) 技術研究所 
溶解中は大気, もしくは CO ガスによる酸素, あるい は炭素の銅浴への溶解老調節寸るため $3 \mathrm{l} / \mathrm{min}$ 以下の Ar ガスを吹き付け, 溶落ち後は Ar $5 l /$ min を鋼浴面 に吹き付け，脱酸後の銅浴が再酸化するのを防いだ．脱 酸剂注電解マンガン $(\mathrm{Mn}>99 \cdot 8 \%)$, 金属シリコン $(99 \cdot$ $4 \%)$, Al は純アルそニウムと電解鉄とから溶製した Fe$\mathrm{Al}(50 \%)$ を使用し，鉄製カブセルに入れ，溶接用の鉄線 に結えて溶鋼に添加し約 $5 \mathrm{sec}$ 程度掜拌した。脱酸剤添 加後は所定の時間に $5 \mathrm{~mm} \phi$ の石英管て鋼浴面から一定 深さより約 $50 \mathrm{~g}$ を採取しただちに水中で急冷した。後 述するがタンマン炉で溶解した静止浴の場合はルツボ内 の深さ方向でおのおの異なつた浮上過程它示すので，試 料採取位置には特に注意を払い一定の深さより試料を採 取した、鋼浴温度は石英管で保蓝した Pt-Pt Rh(13\%) で, 2〜4 min ごとに測定した・採取試料は真空溶融法に よる酸素分析，シリコンについてはモりブデン青による 吸光光度洁3)，アルミニウムはアルミノン法，マンガン は過硫酸アンモン法によりおのおの定量した。また介在 物分析については, 適時, 酸法, あるいはヨードアルコ 一ル法を用いた。脱酸戍の組合せは, 基礎的な知識を得 るため, まずシリコン単独脱酸, アルミニウム単独脱酸 を行ない, 添加量, および鋼浴温度による影響を調べ た. 次にマンガンの影響を知るため，マンガンとシリコ ンによる共同脱酸，およびマンガンとアルえニウムによ る共同脱酸を行なつた．次にマンガンとシリコンとアル そニウムによる 3 元共同脱酸を行ない添加量と鋼浴温度 による影響を調査した．また摫找浴における1次脱酸生 成物の浮上分離機構を明らかにするためルツボの材質が 脱酸速度に与える影響を調査した，最後にこれらの基礎 実験による結果を応用し，清浄鋼を得るための現場的な 改善策を提案した。

\section{3. 実 験 結 果}

\section{$3 \cdot 1$ 攂找浴における脱酸速度について}

\section{$3 \cdot 1 \cdot 1$ シリコン脱酸4)}

まずシリコン添加量による影響を見るため, $1600^{\circ} \mathrm{C}$ の銅浴に Si $0.15 \% ， 0.3 \% ， 0.6 \%$ おのおの添加して 脱酸過程を調べた。結果を Fig. I (A), ( B ), (C), (D) に示した. Si注添加後 $0.5 \mathrm{~min}$ までに均一に溶解し,そ の後多少ホーーラスな $\mathrm{MgO}$ ルツボ壁に吸収されている $(\mathrm{FeO})$ が鋼浴に酸素を供給するため酸化減少する。 Si の酸化減少速度を $\mathrm{FeO}-\mathrm{MgO}_{\mathrm{sat}}$ スラツグからの酸素の 供給速度として計算すると $D=3 \times 10^{-5} \mathrm{~cm}^{2} \mathrm{sec}^{-1}$ とな りスラッグからの酸素の昖散定数として無理のない值が 得られたた。したがつて $\mathrm{T}[\mathrm{O}]$ の減少汸脱酸戍添加によ
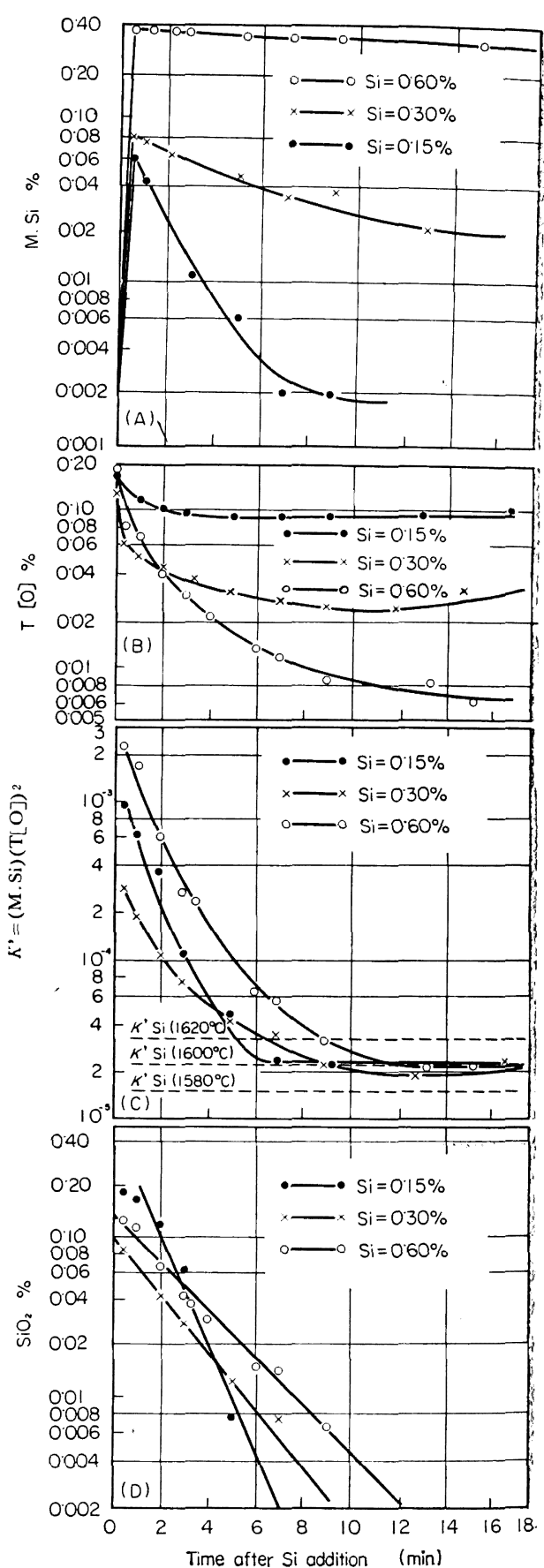

Fig. 1(A), (B), (C), (D). Runs of Si deoxidation as influenced by amount of $\mathrm{Si}$.

つて鋼浴中に生成した $\mathrm{SiO}_{2}$ 介在物の減少によるもので, 均一に溶解した後の $\mathrm{Si}$ の酸化減少によつて生成した $\mathrm{SiO}_{2}$ はルツボとの界面で生成するから, 鋼浴内部の $\mathrm{SiO}_{2}=$ 
とは無関係である。T $[\mathrm{O}]$ 脱酸直後に大きく減少し, その後徐々に減少する。実験中の観察および試料中の介 在物影鏡から, 脱酸直後には $\mathrm{FeO}$ を多く含み, 最大70 $\mu$ 程度までに凝集成長した 1 次介在物の浮上分唯によつ てT [O] は減少する.脱酸約 $0.5 \mathrm{~mm}$ 以後は, 浴内の均 一反応(1)によつて生じた $\mathrm{FeO}$ の少ない $\mathrm{SiO}_{2}$ 介在物

$$
\mathrm{Si}+\mathrm{O} \rightarrow\left(\mathrm{SiO}_{2}\right) \rightarrow \text { 浮上分㠛. }
$$

の浮上分離によつて $\mathrm{T}[\mathrm{O}]$ が減少与る.1 次脱酸生成物 が浮上分離すれば, $K^{\prime}=(\mathrm{M} . \mathrm{Si})(\mathrm{T}[\mathrm{O}])^{2}$ は MAтовA 5 5 ) の $\mathrm{Si}-\mathrm{O}$ 系平衡値と一致する。この時点はたとえば $\mathrm{Si}$ $0.3 \%$ の場合 $8 \mathrm{~min}$ である. 次に 1 次脱酸生成物の量的 変化は M.Si が溶鋼中の金属シリコンであるから ${ }^{376), ~}$ (2)式より計算した。

Fig. 1 (D)に示すとおり,脱酸 $0.5 \mathrm{~min}$ 以後は時間に対

$$
\mathrm{SiO}_{2} \%=\left(\mathrm{T}[\mathrm{O}]-\sqrt{K_{\mathrm{S}_{1}}^{\prime} / \mathrm{M} . \mathrm{Si}}\right) \times \frac{60}{32} \cdots
$$

$\mathrm{L}$, 対数的に浮上分離する. 寸なわち $\mathrm{C}=\mathrm{Co} \exp (-k \mathrm{t})$ の形式にしたがつている。ただし $\mathrm{t}$ は時間で， $k$ は浮上 分離倸数である. $\mathrm{t}$ を $\min$ とすると，

Si $0.15 \%$ 脱酸 $\mathrm{SiO}_{2}(\%)=0.480 \exp (-0.80 \mathrm{t})$

Si $0.30 \%$ 脱酸 $\mathrm{SiO}_{2}(\%)=0.105 \exp (-0.43 \mathrm{t})$

Si $0.60 \%$ 脱酸 $\mathrm{SiO}_{2}(\%)=0.150 \exp (-0.35 \mathrm{t})$ つきに鋼浴程度の影響を見るため， $1560^{\circ} \mathrm{C} と 1650^{\circ} \mathrm{C} の$ 鋼浴て，おのおの Si $0.3 \%$ 脱酸を行なつた結果，

$1650^{\circ} \mathrm{C}$ の場台 $\mathrm{SiO}_{2}(\%)=0.220 \exp (-0.74 \mathrm{t})$

$1560^{\circ} \mathrm{C}$ の場合 $\mathrm{SiO}_{2}(\%)=0.140 \exp (-0.34 \mathrm{t})$ 以上の結果 $\mathrm{SiO}_{2}$ 介在物の浮上分離係数 $k$ は脱酸剂の添 加量が少ないほど，また鋼浴温度が高いほど大きくなる ことがわかつた，試料の顕微鏡観察，および X.M.A. による介在物定量分析234) 結果脱酸後 $0.5 \mathrm{~min}$ までは $30 \mu$ 以下の $\mathrm{SiO}_{2}$ 介在物の他, $\mathrm{FeO}$ を $40 \%$ 程度含屯 $\mathrm{FeO}-\mathrm{SiO}_{2}$ 介在物が存在し, 最大 $70 \mu$ まで㠜集成長し， $\mathrm{FeO}-\mathrm{SiO}_{2}$ 采介在物の凝集性がよいことを示していた。 脱酸 $1 \mathrm{~min}$ 以後は通常の $\mathrm{SiO}_{2}$ 粒子のみであつた。

\section{$3 \cdot 1 \cdot 2$ アルミニウム脱酸门}

$\mathrm{Al}$ による脱酸は工学的に最も重要であるにもかかわ ら方速度論的研究は皆無である。そこで $\mathrm{Si}$ 脱酸にひき つうき全く同様な手法で $\mathrm{Al}$ 脱酸の解析を行なつた。予 備実験から純アルミニウムは不均一に溶解することがわ かり，以下純鉄と純アルミニウムとから溶製した $\mathrm{Fe}-\mathrm{Al}$ (Al 50\%) を使用した。 Fig. 2 (A)，（B)，(C) は Al $0.3 \%$ をおのおの $1550^{\circ} \mathrm{C}, 1600^{\circ} \mathrm{C}, 1650^{\circ} \mathrm{C}$ の鋼浴に 添加した洔の脱酸過程てある. 興味ある点は鋼浴温度が 高いほど $\mathrm{Al}$ の溶鋼への溶解性が劣り, 溶解寸る前に浮 上して酸化する. $\mathrm{T}[\mathrm{O}]$ は $\mathrm{Al}$ の歩留りが大きいほど， すなわち鋼浴温度が低いほよ゙讯速に減少している. Al-O

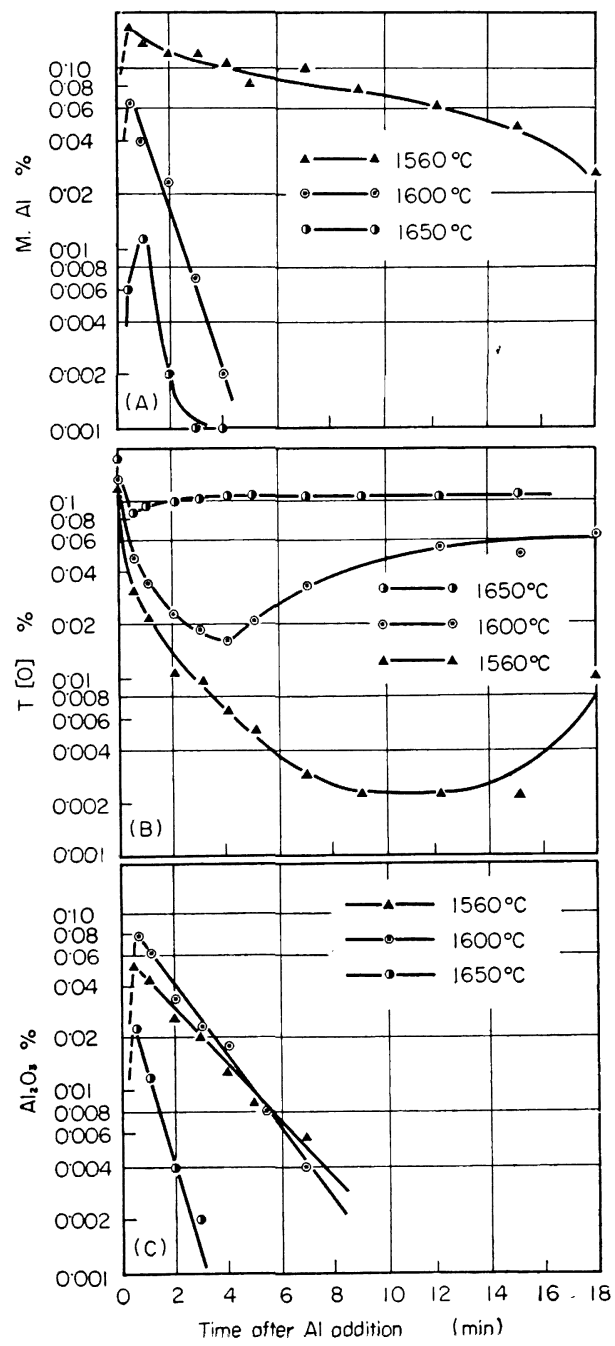

Fig. 2(A), (B), (C). Run of $\mathrm{Al}$ deoxidation, as influenced by bath temperature.

采の平衡から考えて $\mathrm{Al} \geqq 0.002 \%$ 以上存在すれば $\mathrm{O} \leqq$ $0.002 \%$ であるから $\mathrm{T}[\mathrm{O}]$ の減少速度は 1 次介在物の減 少速度である.しかし $1650^{\circ} \mathrm{C} ， 1600^{\circ} \mathrm{C}$ では M.Al が $0.01 \%$ 以下に酸化減少するとルツボ内壁に吸収された $\mathrm{FeO}$ によつて再び鋼浴酸素が増加するが，一方では鋼 浴内の 1 次介在物の減少はひきつづき進行する. M.Al は酸溶解法に上る分析值で, $\mathrm{FeO} \cdot \mathrm{Al}_{2} \mathrm{O}_{3}$ 介在物は酸に 溶解するため，この $\mathrm{Al}$ 分をも含えでおり，真の $\mathrm{Al} よ$ り高い点老考虙する必要がある。一方酸溶解法による $\mathrm{Al}_{2} \mathrm{O}_{3}$ 分析值は溶鋼中の $\alpha-\mathrm{Al}_{2} \mathrm{O}_{3}$ 粒子の分析值で, $\mathrm{FeO} \cdot \mathrm{Al}_{2} \mathrm{O}_{3}$ 介在物の $\mathrm{Al}_{2} \mathrm{O}_{3}$ 分を含えでいない. 介在物 の顕微鏡推察，掞よび X.M.A.による定量分析から， 
$1560^{\circ} \mathrm{C}$ の埸们怯 $\alpha-\mathrm{Al}_{2} \mathrm{O}_{3}$ 分王体てあり, $1600 \mathrm{C}, 1650$ ${ }^{\circ} \mathrm{C}$ では $\alpha-\mathrm{Al}_{2} \mathrm{O}_{3}$ と $\mathrm{FeO}-\mathrm{Al}_{2} \mathrm{O}_{3}$ が主体であつた、上

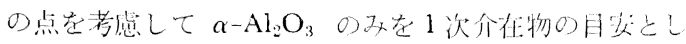

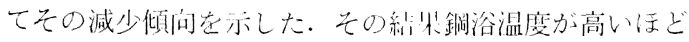
$\alpha-\mathrm{Al}_{2} \mathrm{O}_{3}$ の浮上分離速度は大きく, $\mathrm{Si}$ 脱酸之同様な傾 向があり，下式によつて表わすこよができる。

$1560^{\circ} \mathrm{C}$ の場合 $\mathrm{Al}_{2} \mathrm{O}_{3}(\%)=0.062 \exp (-0.33 \mathrm{t})$

$1600^{\circ} \mathrm{C}$ の)場合 $\mathrm{Al}_{2} \mathrm{O}_{3}(\%)=0.092 \exp (-0.42 \mathrm{t})$

$1650^{\circ} \mathrm{C}$ の場合 $\mathrm{Al}_{2} \mathrm{O}_{3}(\%)=0.038 \exp (-0.94 \mathrm{t})$ 次に脱酸剂添加量の影蠁を調べるため $1600^{\circ} \mathrm{C}$ の鋼浴

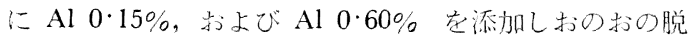
酸過程を調バた. Al 0.6\% 脱酸ては $\mathrm{Al}$ の鋼浴への溶 解熱のため鋼浴温度は $1660^{\circ} \mathrm{C}$ となり温度の影響が強く 現われた。 $\alpha-\mathrm{Al}_{2} \mathrm{O}_{3}$ 浮上分睢速度は，おのおの下式のと おりであつた。

Al $0.15 \%$ 脱酸 $\mathrm{Al}_{2} \mathrm{O}_{3}(\%)=0.012 \exp (-0.63 \mathrm{t})$ $\left(1600^{\circ} \mathrm{C}\right)$

Al $0.60 \%$ 脱酸 $\mathrm{Al}_{2} \mathrm{O}_{3}(\%)=0.068 \exp (-0.75 \mathrm{t})$ $\left(1660^{\circ} \mathrm{C}\right)$ 介在物の顕微鏡観察では Al $0.6 \%$ 脱酸の研磨面て観察 される $\mathrm{Al}$ 脱酸に共通したクラスター状の $\alpha-\mathrm{Al}_{2} \mathrm{O}_{3}$ の 集団は，ヨードアルコール法侄よる抽出残椬では長さ 20 $\mu$ 程度のデンドライト状の $\alpha-\mathrm{Al}_{2} \mathrm{O}_{3}$ であり, 研磨面で は 1 個 $5 \mu$ 程度であるが実際はこれより数倍の大きさで

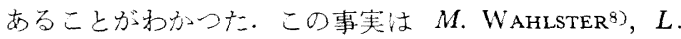
V. BOGDANDY ${ }^{9)}$ 同様に確認している.

$3 \cdot 1 \cdot 3$ マンガンとシリコンによる共同脱酸10)

現場的には Si 単独よりも Mn と共に使用する場合が 多い，そこで Si 単独脱酸との比較の意味から $\mathrm{Mn} 0{ }_{5}$ $\%$ と Si $0.3 \%$, 执よび $\mathrm{Mn} 1 \%$ と Si $0.3 \%$ を打の おの $1600^{\circ} \mathrm{C}$ の鍓浴に添加し, Si $0.3 \%$ 脱酸と比較し た.Fig. $3(\mathrm{~A})$ ，（B）にその脱酸過程圭示した。紙面の 都台上略したが Mn は共に約 95\% 歩留りを示したが， M.Si はMn 源加量が多いほど歩留りがよく, Mn が脱 酸反応に関与していることが明らかとなつた。T[O]は $\mathrm{Mn}$ 名多くなると，脱酸 $0.5 \mathrm{~min}$ までに著しく減少声 る.ここで脱酸反応考蔡吉ると 2 つ素反応がある.

$$
\begin{aligned}
& \mathrm{Mn}+\mathrm{O} \rightarrow \mathrm{Mn}^{2+}+\mathrm{O}^{2-} \\
& \mathrm{Si}+2 \mathrm{O} \rightarrow \mathrm{Si}^{4+}+2 \mathrm{O}^{2-}
\end{aligned}
$$

$\mathrm{Mn}-\mathrm{O}$ 系平衡から考えて Mn 0.5\%の場合は（4）が先 行し, $\mathrm{SiO}_{2}$ 分在物が生成する。この $\mathrm{SiO}_{2}$ 介在物表面 は $\mathrm{SiO}_{2}$ 飽和スラッグであるから $a_{\mathrm{MnO}}$ は急激に低下 (11)，(3)反応が進行吉了（3)反応によつて $\mathrm{SiO}_{2}$ 介 在物の表面が $(\mathrm{MnO})$ によつて覆われると $a_{\mathrm{SiO}_{2}}$ も低下 するので（4）反応も再び進行する.Mn 1\%の場合は

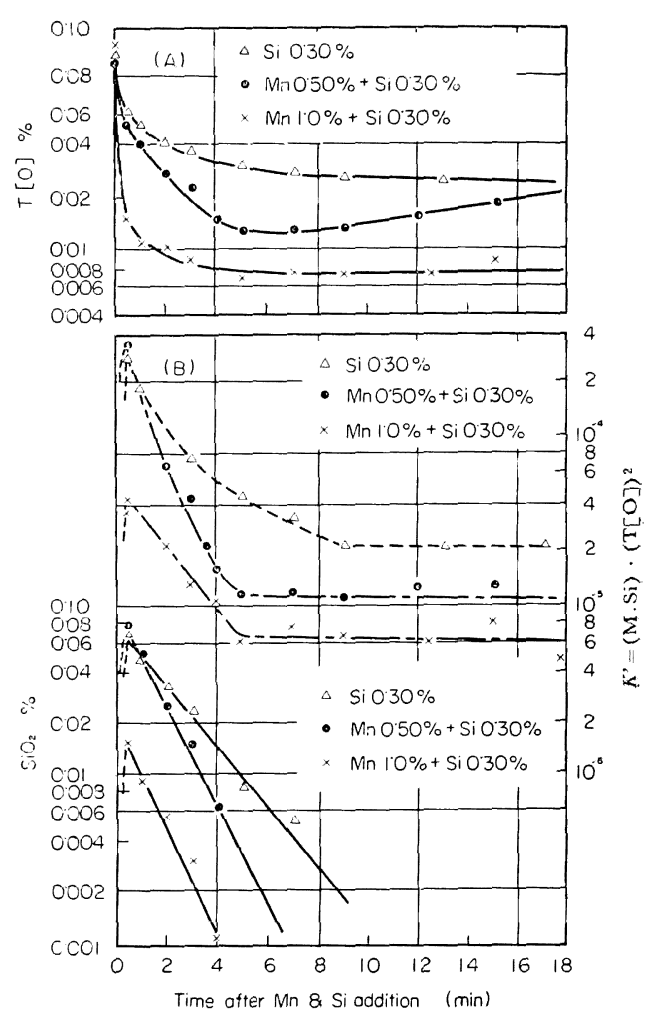

Fig. 3(A), (B). Run of $\mathrm{Mn}$ and $\mathrm{Si}$ complexdeoxidation.

（3），(4)反応は同様に進行する.この推論は介在物の X.M.A による定量分析で, $\mathrm{Mn} \mathrm{0.5 \%} \mathrm{では中心が} \mathrm{SiO}_{2}$ 飽和で, 外周が液相の $\mathrm{MnO}-\mathrm{SiO}_{2}$ 系介在物であり, $\mathrm{Mn}$ $1 \%$ の場台は中心も外周も液相の $\mathrm{MnO}-\mathrm{SiO}_{2}$ 采介在物 であることから確認された。 介在物の外周組成は KÖRBER，OELSEN $\left.{ }^{12}\right) ら の$ 実験結果と一致していた. $K^{\prime}=(\mathrm{M}$. $\mathrm{Si})(\mathrm{T}[\mathrm{O}])^{2}$ は1 次介在物が浮上分離した後は一定値を 保ち, $a_{\mathrm{SiO}_{2}}<1$ となつて $\mathrm{Mn}$ の共同脱酸勃果を示す.

$K^{\prime}$ の值から $a_{\mathrm{SiO}_{2}}$ 老計算すると $\mathrm{Mn} 0.5 \%$ では $a_{\mathrm{SiO}_{2}}$ $=0.50, \mathrm{Mn} 1 \%$ では $a_{\mathrm{SiO}_{2}}=0.29$ であり, HiLTY,

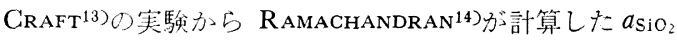
とも一致していた１次介在物量の組成は $\mathrm{MnO}-\mathrm{SiO}_{2} て ゙$ あるが比較のため $\mathrm{SiO}_{2}$ と見なして計算した（ $\left.\mathrm{T}[\mathrm{O}]_{\mathrm{eq}}\right) \times 60 / 32$ によつてその浮上速度を求めた。ここ こ $\mathrm{T}[\mathrm{O}]_{\mathrm{eq}}$ は 1 次介在物が浮上した時点の酸素量でFig. 3 の $\mathrm{T}[\mathrm{O}]$ の最小值である。

$\mathrm{Mn} 0.5 \%+\mathrm{Si} 0.3 \%$ 脱酸 $\mathrm{SiO}_{2}(\%)=0.100 \exp$ $(-0.63 t)$.

$\mathrm{Mn} 1 \cdot 0 \%+\mathrm{Si} 0 \cdot 3 \%$ 脱酸 $\mathrm{SiO}_{2}(\%)=0.022 \exp$ $(-0.69 t)$. 


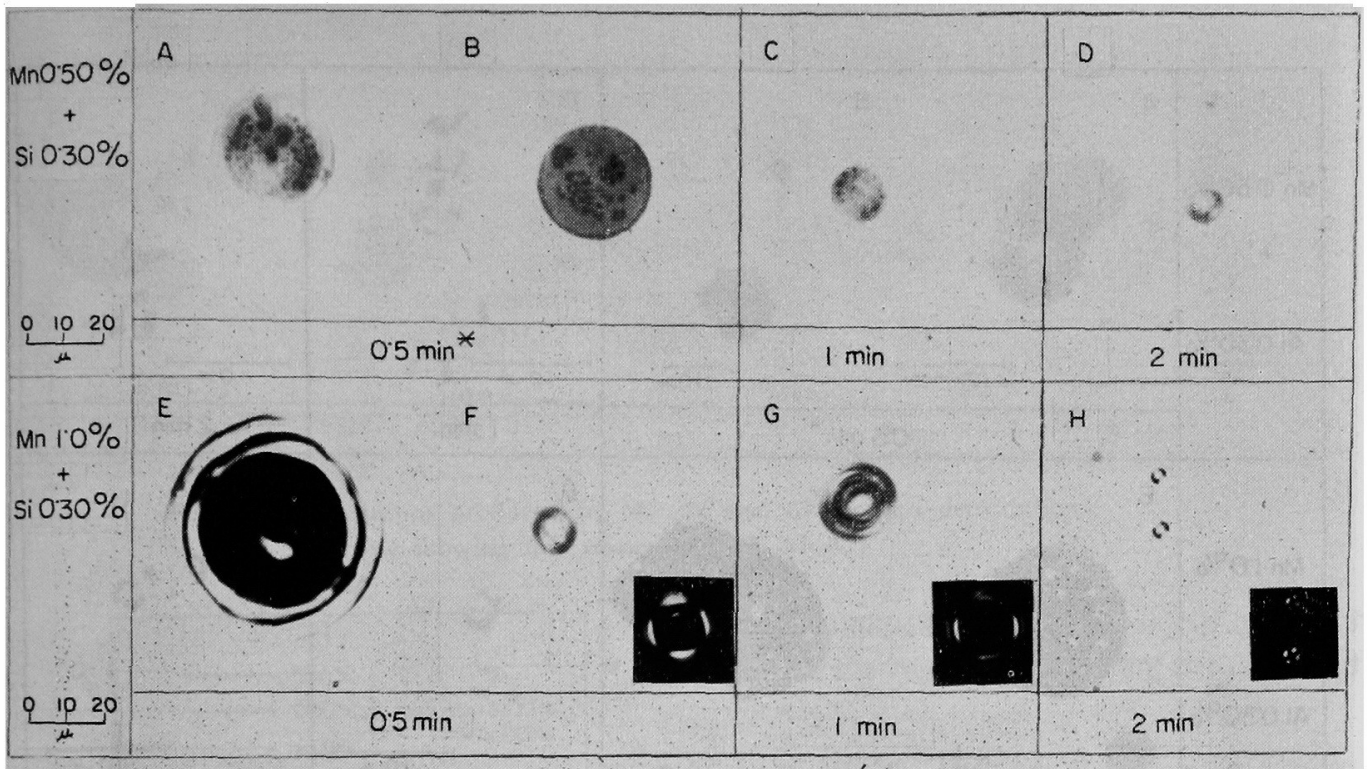

(*) Timie after deoxidizer addition

Photo. 1. Inclusions produced at $\mathrm{Mn}$ and $\mathrm{Si}$ complex-deoxidation.

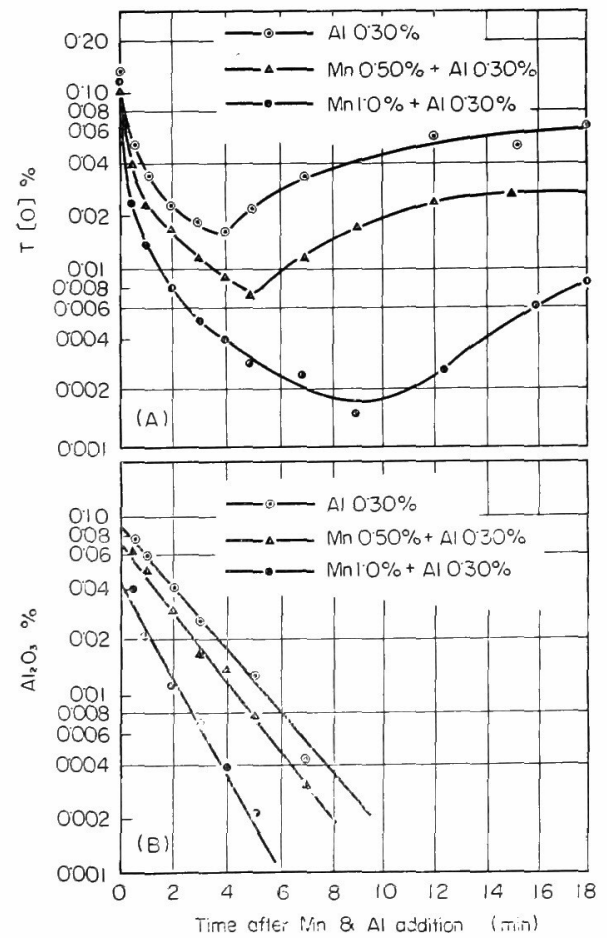

Fig. 4 (A), (B). Runs of $\mathrm{Mn}$ and $\mathrm{Al}$ complexdecxidation.

以上のと新り，Mn が共存直ると1次介在物の浮上速度
も速くなる．介在物の顕䘗鏡観察では Mn 添加量が多く なると脱酸直後 $(0.5 \mathrm{~min})$ の最大粒子径は大きく, 0.5 minまでの T[O] の減少を説明している (Photo. 1). しかし $1 \mathrm{~min}$ 以後はもしる Mn 1\% の場合が粒子往が 小さく浮上分改保数は介在物の大きさにはよらないこと が明らかであつた。この点については浮上分離の機棈か 与説明主豆。

$$
3 \cdot 1 \cdot 4 \text { マンガンとアルミニウムによる共同脱酸15) }
$$

$\mathrm{Al}$ 単独脱酸と比較して $\mathrm{Mn}$ と $\mathrm{Al}$ による共同脱酸の 効果をあきらかにするため $\mathrm{Mn} 0.5 \%$ と $\mathrm{Al} \mathrm{C} \cdot 3 \%$ ，お

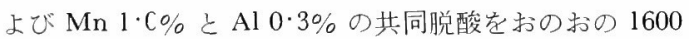
“Cの鋼浴で行ない; 脱酸過程を調べた。Fig. 4(A), （B）にその一部老示した．Mn の添加量が多いほど M. $\mathrm{Al}$ の歩留りがよく, あきらかに Mn が脱酸反応に関与 していることがわかつた．脱酸 $0.5 \mathrm{~min}$ の試料进顕微鏡 で観察すると最大 $40 \mu$ までの $\mathrm{MnO}-\mathrm{Al}_{2} \mathrm{O}_{3}$ 系介在物が存 在し, X.M.A の定量分析こは約 $40 \%$ の $\mathrm{MnO}$ 台含九 でいた(Photo. 2, A , B E E)。このように脱酸初期には $\mathrm{MnO}$ 劣含光凝集成長した 1 次介在物が存在し，これが 急激に浮上することな：T[O] の急激な減少在説明して いる。このような介在物は0.5 minまてに浮上し，1 min 以後は $\mathrm{Al}$ 乙平衡する $\alpha-\mathrm{Al}_{2} \mathrm{O}_{3}$ のみが観察された。 そ こで酸法によつて抽出した $\mathrm{Al}_{2} \mathrm{O}_{3}$ を1 次介在物としてそ の浮上分雜涑度安調ベた結果，おのおの下式で表わすこ 


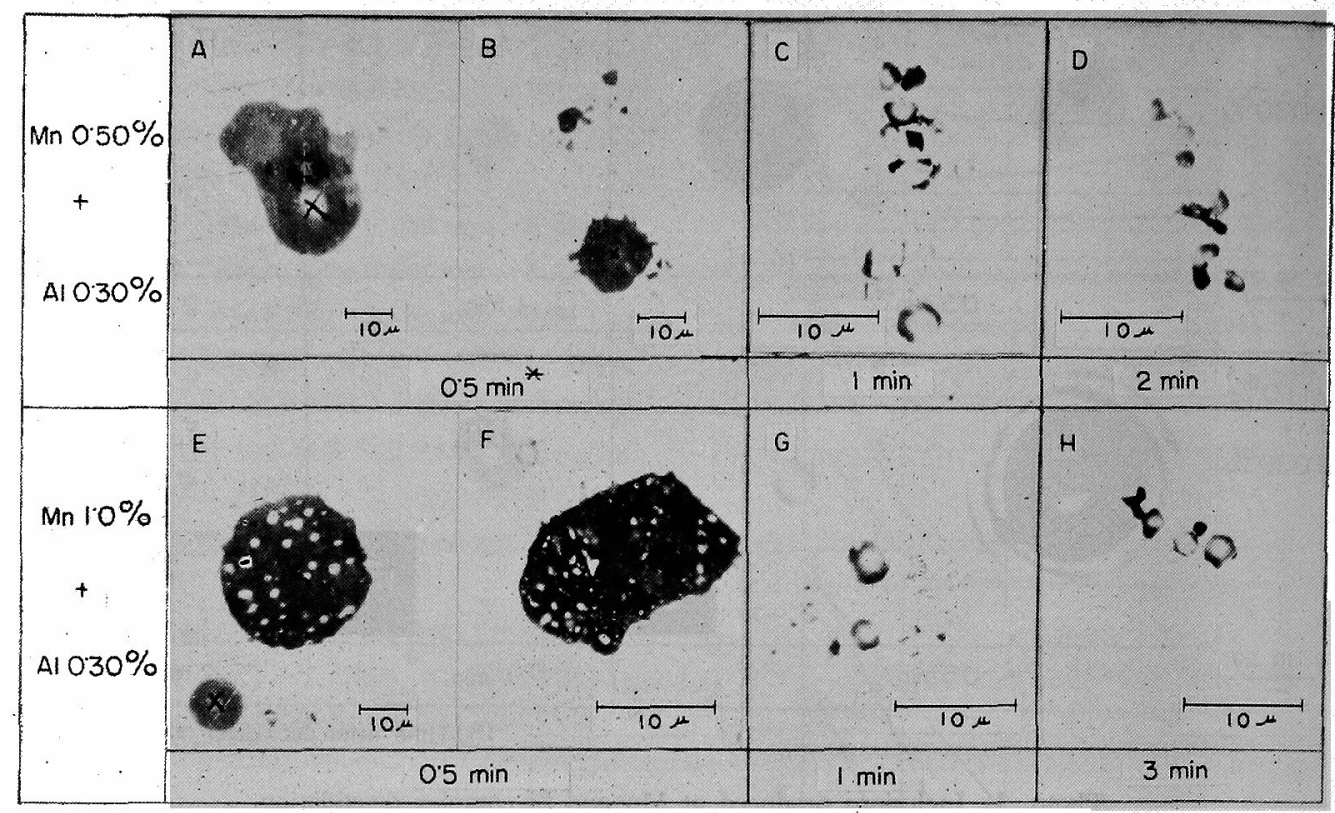

(*) Time after deoxidizer addition

Photo. 2. Inclusions produced by $\mathrm{Mn}$ and $\mathrm{Al}$ complex-deoxidation.

(X: analysed spot by X.M.A)

とができる。

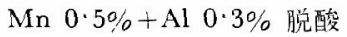

$$
\mathrm{Al}_{2} \mathrm{O}_{3}(\%)=0.078 \exp (-0.52 \mathrm{t})
$$

$\mathrm{Mn} 1 \cdot 0 \%+\mathrm{Al} 0 \cdot 3 \%$ 脱酸

$$
\mathrm{Al}_{2} \mathrm{O}_{3}(\%)=0.050 \exp (-0.63 \mathrm{t})
$$

上記のとおり, Mn 添加量が多いほど浮上分離速度は速 くなる・しかし介在物の顕微鏡観察では, Mn 添加量にか かわらず $0.5 \mathrm{~min}$ 以後は同じ大きさであつた (Photo. 2) 浮上分離はストークス法則によらないこと交してい た.また酸法による $\mathrm{Al}_{2} \mathrm{O}_{3}$ 分析值の $1 / 2$ がほぼ $\mathrm{T}[\mathrm{O}]$ と一致し, $\mathrm{T}[\mathrm{O}]$ は同時に $\mathrm{Al}_{2} \mathrm{O}_{3}$ 介在物によるもので あることを確認した。

$3 \cdot 1 \cdot 5$ マンガンとシリコンとアルミニウムによる共 同脱酸

通常キルド鋼では取鍋に㧍ける最終脱酸で $\mathrm{Mn}$ と $\mathrm{Si}$ とAlによる 3 元共同脱酸を行なう。そこで Mn 添加量は $0.5 \%$ とし, Si 添加量を $0.15 \%, 0.30 \%, 0.60 \%, \mathrm{Al}$ 添加量を $0.15 \% ， 0.30 \% ， 0.60 \%$ 七しこれを組合せて $1600^{\circ} \mathrm{C}$ の鋼浴に添加して, Si 添加量を一定とした時の Al 量による影響，および $\mathrm{Al}$ 添加量を一定とした時の Si 添加量の影響を調べた。また Mn $0.5 \%$ Si 0.30
$\%$, と $\mathrm{Al} 0 \cdot 30 \%$ を $1650^{\circ} \mathrm{C}$ および $1550^{\circ} \mathrm{C}$ の鋼浴に おのおの添加して鋼浴温度の影響を調べた、鈮浴温度の 影響を Fig. 5 (A)，(B) に示した.ここでも脱酸 0.5 $\min$ て脱酸前の $\mathrm{T}[\mathrm{O}]$ は約 $80 \%$ 減少，共同脱酸効果 が認るられた. $0.5 \mathrm{~min}$ の試料安顕微鏡で観察し， X. M.A によつて定量分析した結果, 凝集成長した $\mathrm{MnO}$ $\mathrm{SiO}_{2}-\mathrm{Al}_{2} \mathrm{O}_{3}$ 介在物と $10 \mu$ 以下の $\alpha-\mathrm{Al}_{2} \mathrm{O}_{3}$ が混在し ていた(Photo. 3). また $\mathrm{MnO}-\mathrm{SiO}_{2}-\mathrm{Al}_{2} \mathrm{O}_{3}$ 采介在物に は $\mathrm{Al}_{2} \mathrm{O}_{3}$ の多い (> $\left.80 \%\right)$ の部分と $\mathrm{Al}_{2} \mathrm{O}_{3}(<30 \%)$ の少 ない部分とにわかれ，後者が前者を吸着したような形式 で存在していた。したがつて脱酸反応は（5）と（6）が 同時に進行したと考えられる.

$$
\begin{aligned}
& a \underline{\mathrm{Mn}}+\underline{b \mathrm{Si}}+2 \mathrm{C} \underline{\mathrm{Al}}(\mathrm{a}+2 \mathrm{~b}+3 \underline{\mathrm{c}}) \mathrm{O} \rightarrow \\
& (\mathrm{MnO})_{a} \cdot\left(\mathrm{SiO}_{2}\right)_{b} \cdot\left(\mathrm{Al}_{2} \mathrm{O}_{3}\right)_{c} \\
& 2 \mathrm{Al}+3 \mathrm{O} \rightarrow \mathrm{Al}_{2} \mathrm{O}_{3}
\end{aligned}
$$

共同脱酸の効果は（5）反応によつて生じた複合介在 物が（6）反応で生じた $\alpha-\mathrm{Al}_{2} \mathrm{O}_{3}$ 分在物と㠜集し，浮 上を促進させる点にある。このような観点からは，脱酸 直後の鋼浴の鄮拌状態は凝集性を促進する意味で重要で ある. $0.5 \mathrm{~min}$ 以後の介在物注顕微鏡観察およびX線回 折の結果 $\alpha-\mathrm{Al}_{2} \mathrm{O}_{3}$ の工であつた. そこでヨードアルコ 


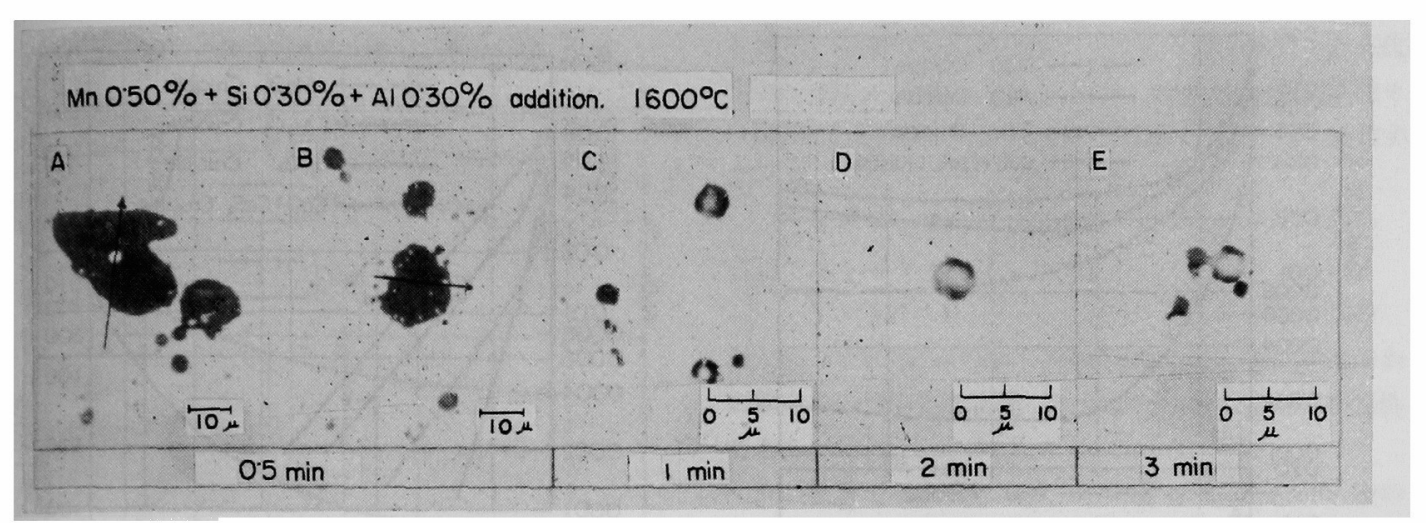

Photo. 3. Inclusions produced by $\mathrm{Mn}, \mathrm{Si}$ and $\mathrm{Al}$ complex-deoxidation. (arrow showing line scanning by X.M.A.)

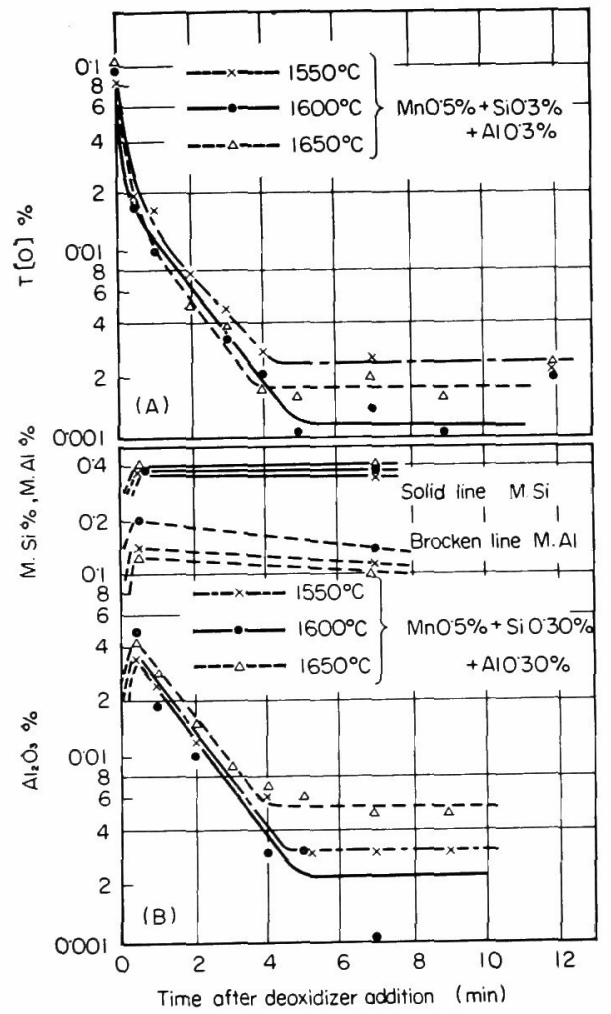

Fig. 5 (A), (B) Run of deoxidation as influenced by the bath temperature.

ール法汇よつて定量した $\mathrm{Al}_{2} \mathrm{O}_{3}$ を検討したところ $\mathrm{T}[\mathrm{O}]$ と化学量論的に一致したのでその浮上速度を調べた (Fig. 5 (B)). $4 \mathrm{~min}$ 以後は一定值となるが，これはヨ ードアルコール法によ方分析が酸法より微量な $\mathrm{Al}_{2} \mathrm{O}_{3}$ ⿸ 検出でき, 一方鋼浴面は Ar ガスでシールしても完全で 然いこ上岩考虑すると浮上する一方では鋼浴面で生成す
る $\mathrm{Al}_{2} \mathrm{O}_{3}$ が鋼浴に巻き込まれ，見かけ上浮上が中止主 る.この值まで $\mathrm{Al}_{2} \mathrm{O}_{3}$ が減少する速度は下式で表わす ことができる.

$$
\mathrm{C}=\mathrm{Co} \exp (-0.62 \mathrm{t})
$$

このように温度による影響はなかつた。また $\mathrm{Al}$ 添加 量，および Si 添加量による影響を調べたが，浮上速度 注すべて（7）式で表わすことができそその影響はなか つた.

$3 \cdot 1 \cdot 6$ ルツボ材が脱酸速度に与える影響 16)

こ机までの実験で，各種の脱酸における1次介在物の 浮上分㒛係数を測定したが，これらの相異は浮上分離機 構があきらかにな机ば説明が吅き，kを大きくする現場 的指針孔得ら机る。そこで $\mathrm{Si} 0.3 \%$ および $\mathrm{Al} 0.3 \%$ 脱酸を㧍のおの $\mathrm{SiO}_{2}$ ルツボ(不透明石英ルツボ), $\mathrm{Al}_{2} \mathrm{O}_{3}$ ルツボ,実験室的に作成した $\mathrm{CaO}-\mathrm{CaF}_{2}(20 \%)$ で行な い，これまでの $\mathrm{MgO}$ ルツボの実騃結果と比較した。 各ルツボの幾何学的形状は $\mathrm{MgO}$ ルツボと同じである。 Fig. 6(A)，（B)，(C) にその脱酸過程を示した．．＇＝ $(\mathrm{M} . \mathrm{Si})(\mathrm{T}[\mathrm{O}])^{2}$ を計算して見ると, $\mathrm{MgO}$ と $\mathrm{SiO}_{2}$ の ルツボでは $\mathrm{Si}-\mathrm{O}$ 系の平衡定数 $K_{\mathrm{Si}}^{\prime}=2 \cdot 4 \times 10^{-4}(1600$ C) に達するが, $\mathrm{Al}_{2} \mathrm{O}_{3}$ ルツボでは $7 \mathrm{~min} て ゙ ~ a_{\mathrm{SiO}_{2}}=$ $0.29, \mathrm{CaO}-\mathrm{CaF}_{2}$ ルツボては $5 \mathrm{~min} て ゙ a_{\mathrm{SiO}_{2}}=0.015$ に 相当する $K_{\mathrm{S} i}^{\prime}$ に到達する. $K_{\mathrm{S} i}^{\prime}$ が最小值に到達する 時点までには1次介在物は完全に浮上していることを考

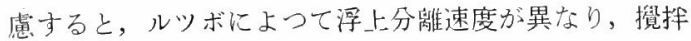
浴における 1 次介在物の浮上分嚄は物理的浮上てないこ とが明らかである。ここで脱酸反応を考察すると浴内反 応は（1）式にしたがい、 $\mathrm{SiO}_{2}$ ある.しかし、たとえは $\mathrm{Al}_{2} \mathrm{O}_{3}$ ルツボては $a_{\mathrm{SiO}_{2}}=0 \cdot 29$ 上 なるから（8）式によるルツボ材との界面反応を考虑し

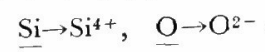



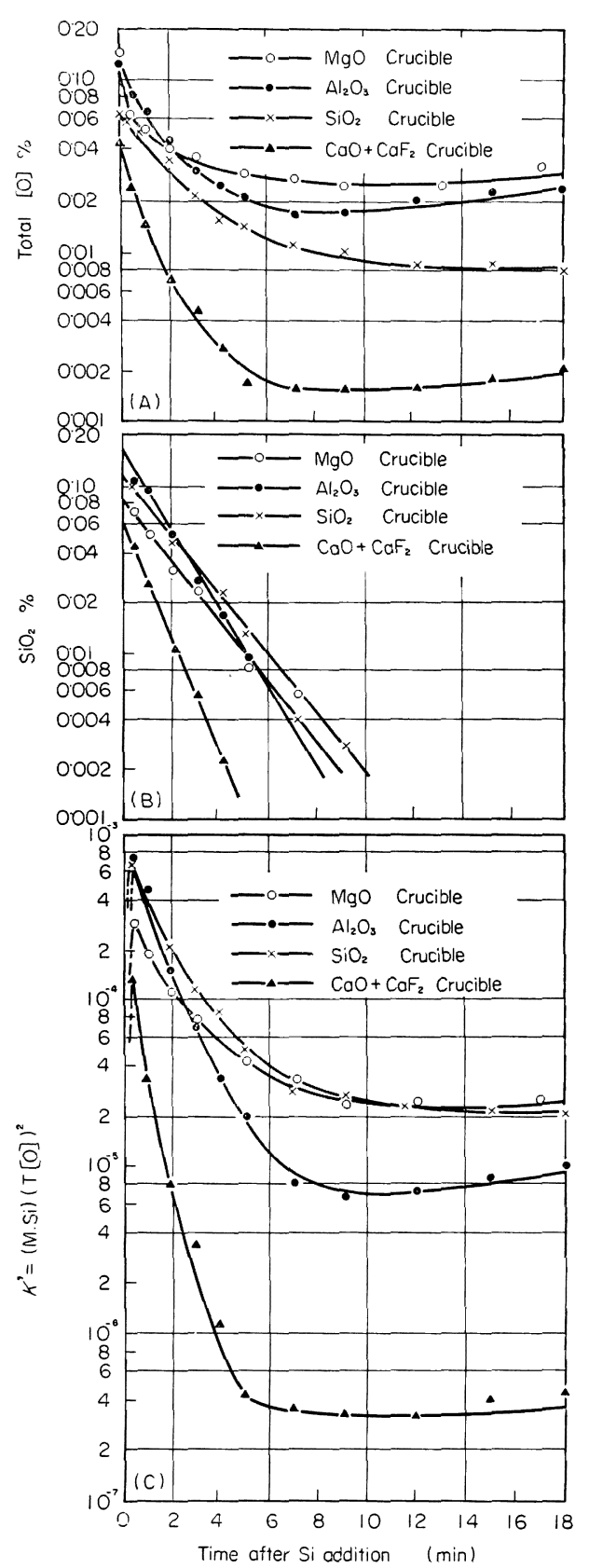

Fig. 6 (A), (B), (C). Run of deoxidation by $0.30 \% \mathrm{Si}$ in different crucibles.

なければならない、すなわち $\mathrm{Al}_{2} \mathrm{O}_{3}$ ルツボと $\mathrm{CaO}-\mathrm{CaF}_{2}$ ルッボでは $\mathrm{T}[\mathrm{O}]$ の減少が 1 次介在物の浮上分離上 (8) 式に上る界面反応にもよつている。(T[O]-T [O $]_{\mathrm{eq}}$ ) 60/ 32 を計算すると $\mathrm{MgO}, \mathrm{SiO}_{2}$ の各ルツボでは 1 次介在 物量であり， $\mathrm{Al}_{2} \mathrm{O}_{3}, \mathrm{CaO}-\mathrm{CaF}_{2}$ の各ルツボでは1次介

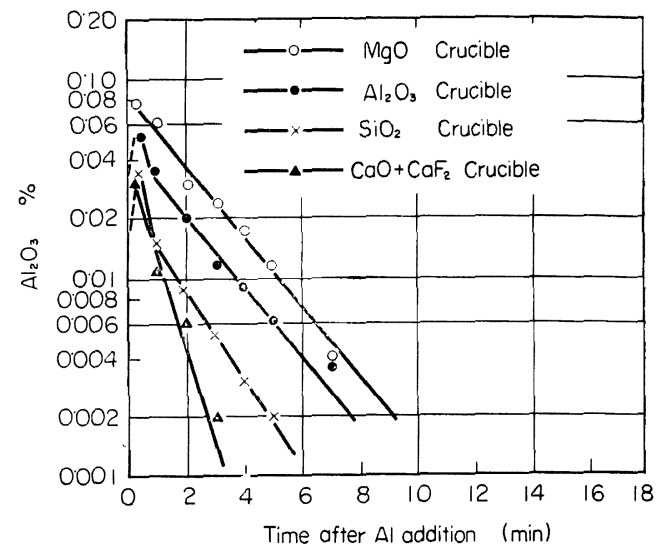

Fig. 7. Run of deoxidation by aluminium in different crucibles.

在物量と拡散脱酸によるOの減少量とを含えでいる.界 面の桩散脱酸でも $a_{\mathrm{SiO}_{2}}<1$ の $\mathrm{SiO}_{2}$ とルツボ材とのス ラッグが生成さ机るから $\mathrm{SiO}_{2}$ としての浮上分離とみな すことができる. 各ルツボにおける $\mathrm{SiO}_{2}$ の浮上分離速 度は下式で表わすことができる。

$$
\begin{array}{ll}
\mathrm{SiO} \text { ルルツボ } & \mathrm{SiO}_{2}(\%)=0.12 \exp (-0.42 \mathrm{t}) \\
\mathrm{MgO} \text { ルツボ } & \mathrm{SiO}_{2}(\%)=0.082 \exp (-0.43 \mathrm{t})^{\prime} \\
\mathrm{Al}_{2} \mathrm{O}_{3} \text { ルッボ } & \mathrm{SiO}_{2}(\%)=0.17 \exp (-0.59 \mathrm{t}) \\
\mathrm{CaO}-\mathrm{CaF}_{2} \text { ルツボ } & \mathrm{SiO}_{2}(\%)=0.080 \exp (-0.93)
\end{array}
$$

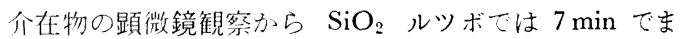
犬゙ $10 \mu の \mathrm{SiO}_{2}$ が観察されるが， $\mathrm{CaO}-\mathrm{CaF}_{2}$ ルツボで は $1 \mathrm{~min} て ゙ 5 !$ 以下の $\mathrm{SiO}_{2}$ 粒子が観察され, 明らか に $\mathrm{CaO}-\mathrm{CaF}_{2}$ ルツボにおける浮上分嶉㹥他のルツボよ りも著しく速い。同樣な手法で $\mathrm{Al} 0.3 \%$ 脱酸を行な つたが, $\mathrm{Al}_{2} \mathrm{O}_{3}, \mathrm{MgO}, \mathrm{SiO}_{2}, \mathrm{CaO}-\mathrm{CaF}_{2}$ ルツボの順 に $\mathrm{Al}_{2} \mathrm{O}_{3}$ 介在物の浮上速度が速くなつている(Fig. 7). これらの結果を総合して考察すると1次介在物と化学的 親和力が強いルツボほよ゙ 1 次介在物の浮上分攡が速く,

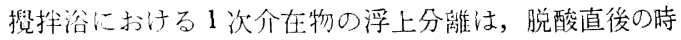
期を除くとストークス法則などによる物理的浮上ではな いことを示している.

\section{$3 \cdot 2$ 静止浴における脱酸速度について17)}

$3 \cdot 2 \cdot 1$ 静止浴に抢ける 1 次介在物の浮上速度式

まず予借実験として Si $0.3 \%$ 脱酸を行ない，T[O] のルツボ深さ方向の変化, 浴内における鋼浴温度分布, 1 次介在物の精度分布を調べた。 Fig. 8 に結果を示し た. 所定時刻に鋼浴面から $30 \mathrm{~mm}$ とルッボ底部より $10 \mathrm{~mm}$ の個所より試料を採取した結果, T[O 向で異なり，1 次介在物が徐々に浮上していることがわ かつた．鋼浴温度は $4 \mathrm{~mm} \phi$ の石英管に Pt-PtRhを择 


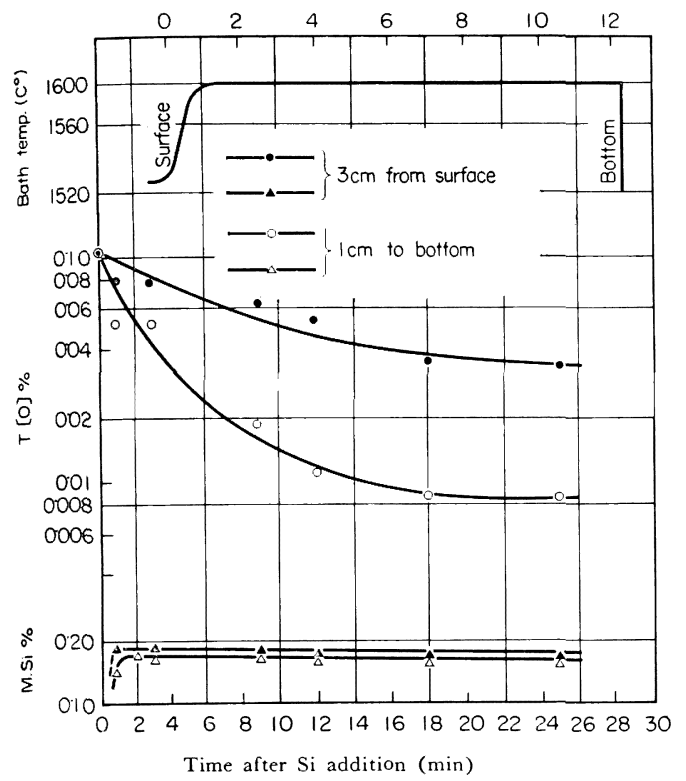

Fig. 8. Run of $0 \cdot 30 \% \mathrm{Si}$ deoxidation in tranquil steel bath at $1600^{\circ} \mathrm{C}$.

入し， $1 \mathrm{~mm} / \mathrm{sec}$ 程度の速度で鋼浴内に押し込み深さ方 向の温度分布を測定した。その結果鋼浴面な５約 $15 \mathrm{~mm}$ を除いては温度は均一であり，対流の少ない鋼浴であろ うと推定した。 以上の点から1次介在物は何らかの物理 的浮上を行なうことを想定し，物理的浮上で最も重要な 1 次介在物の粒度分布を測定するため, 脱酸後 $0.5 \mathrm{~min}$ と $1 \mathrm{~min}$ の試料から，ヨードアルコール法による残椬 抽出を行ない，顕微鏡写真を多数とつて粒度測定を行な つた．抽出残椬は少量の界面活性削を加えた水滴で分散 させて顕微鏡写真にとつた・約 3000 個の測定から介在 物の粒度分布は下式で表わすことができる。

$n=n_{0} \exp (-A \mathrm{r})$

$\mathrm{r}$ : 介在物半径, $n, n_{0}$ : 半径 $\mathrm{r}$ および $\mathrm{r} \rightarrow 0$ の粒子の 個数

（9)式を基準化すれば，

$$
\begin{gathered}
1=\int_{\mathrm{r}=0}^{\mathrm{r}=\infty} \mathrm{n} d \mathrm{r}=n_{0} \int_{\mathrm{r}=0}^{\mathrm{r}=\infty} \exp (-A \mathrm{r}) d \mathrm{r} \\
\text { よつて (9) は }
\end{gathered}
$$

1 次介在物の浮上速度を数式化怙るため次の仮定を立て t.

（a）溶鋼は対流の少ない静止浴であり，1次介在物 の物理的浮上を妨げない。

(b) 1 次介在物の浮上はストークス法則に良う.

(c) 脱酸剂添加後ただちに生成する1次介在物は， 浮上途中に凝集しない。

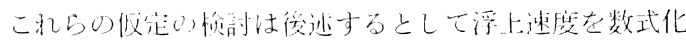
する。錩浴中でルツボ底より $\mathrm{h}(\mathrm{cm})$ ○面:, 半径 $\mathrm{r}$ $(\mathrm{cm})$ の介在物が $\mathrm{V}(\mathrm{cm} / \mathrm{sec})$ の速度老浮上して到達主 ると志,

$$
\mathrm{h}=\mathrm{Vt} \quad \mathrm{t}: \min .
$$

ここでストークス法則より，

$$
\mathrm{V}=k \mathrm{r}^{2}
$$

たたし $k=60(2 / 9)\left(\rho_{\mathrm{Fe}}-\rho_{2}\right) \mathrm{g} / \eta_{\mathrm{Fe}}, \rho_{\mathrm{Fe}}, \rho_{2}$ はおの打 の鋼浴打よび介在物宫度 $\left(\mathrm{g} / \mathrm{cm}^{3}\right), \quad \eta \mathrm{Fe}$ 注鋼浴の粘性 である。

$\mathrm{h}$ の位置で $\mathrm{t}=0$ の 1 次介在物量を $\mathrm{C}_{\mathrm{o}}, \mathrm{t} \min$ 後の そ机老 $\mathrm{C}_{\mathrm{t}}$ と寸机ば，(11)，（12）式から決まる半径 $\mathrm{r}$ 以上の粒子はすでに浮上している。（10)式在(9)式に代 入して 1 次介在物の体積分布 $W(r)$ を求めると,

$$
\begin{aligned}
& \mathrm{W}(\mathrm{r}) d \mathrm{r}=(4 / 3) \pi \mathrm{r}^{3} A e^{-A \mathrm{r}} d \mathrm{r} / \\
& \int_{0}^{\infty}(4 / 3) \pi \mathrm{r}^{3} A e^{-A \mathrm{r}} d \mathrm{r}=\left(A^{4} / 6\right) \mathrm{r}^{3} e^{-A \mathrm{r}} d \mathrm{r}
\end{aligned}
$$

(13)式から

$$
\begin{aligned}
& \mathrm{C} / \mathrm{C}_{\mathrm{o}}=1-\int_{0}^{\infty} \mathrm{W}(\mathrm{r}) d \mathrm{r}=1-(1 / 6) e^{-A \mathrm{r}} \\
& {\left[(A \mathrm{r})^{3}+3(A \mathrm{r})^{2}+6(A \mathrm{r})+6\right] \ldots \ldots \ldots \ldots \ldots}
\end{aligned}
$$

ここで (12) 式より $\mathrm{r}=\mathrm{h}(/ k \mathrm{t})^{1 / 2}$ であるから

$\mathrm{C} / \mathrm{C}_{\mathrm{O}}=1-(1 / 6) e^{-(\mathrm{h} / k \mathrm{t}>1 / 2}$

$\left[A^{3}(\mathrm{~h} / k \mathrm{t})^{3 / 2}+3 A^{2}(\mathrm{~h} / k \mathrm{t})+6 A(\mathrm{~h} / k \mathrm{t})^{1 / 2}+6\right](15)$

(15) 式がルツボ内高至 $\mathrm{h}$ にすける時間 $\mathrm{t} の 1$ 次介在物 量である。(15)式は複雑てあるからあらかじめ適当な $A$ を入れて計算しておき実験結果と対比することにした。 定数とし $\mathrm{h}=6 \mathrm{~cm}, k$ は, $\rho_{\mathrm{Fe}}=7 \cdot 2 \mathrm{~g} / \mathrm{cm}^{3}, \mathrm{SiO}_{2}$ に対 ᄂ $\rho_{2}=2 \cdot 2\left(\mathrm{~g} / \mathrm{cm}^{3}\right), \mathrm{Al}_{2} \mathrm{O}_{3}$ に対し $\rho_{2}=4 \cdot 0\left(\mathrm{~g} / \mathrm{cm}^{3}\right)$, $\eta_{\mathrm{Fe}}=0.062$ (poise) $\left(1600^{\circ} \mathrm{C}\right)^{18)}$ として計算した。

\section{$3 \cdot 2 \cdot 2$ シリコン脱酸 17}

$1550^{\circ} \mathrm{C}, 1600^{\circ} \mathrm{C}, 1650^{\circ} \mathrm{C}$ の鋼浴をおのおの Si $0 \cdot 3$ \%で脱酸し，脱酸過程莸調べた. Fig. 9 (A)，（B）に $1600^{\circ} \mathrm{C}$ の脱酸過程を詳細に示した。高周波掜拌浴と異 なり, $\mathrm{T}[\mathrm{O}]$ の減少速度は小さく, 1 次介在物の浮上速 度はきわ的て遅い， $K_{\text {Si }}^{\prime}$ は $30 \mathrm{~min}$ でも平衡值に到達せ 寸゙，この時点まてに 1 次介在物の浮上が完了していない ことを示している.1 次介在物の時間的変化は（2）式 で計算した。こ机をFig. 9(B)に示し，同時に (15)式 に適当な粒度分布倸数 $A$ を入觉入て計算した結果も示し た。质の結果 $1550^{\circ} \mathrm{C}$ の場公壮 $A=5 \times 10^{3}, 1600^{\circ} \mathrm{C}$ は $A=4 \times 10^{3}, 1650^{\circ} \mathrm{C}$ 洁 $A=4 \times 10^{3}$ の浮上曲線に乘つて いる (Fig. 10(A), (B)). そここ脱酸 $0.5 \mathrm{~min}$ の試料 からヨードアルコールー线㳭怙出を行ない, 影微鏡写真 による粒度測定苞行なつた。これ在基準化して Fig. 11 に示した。な扮測定数はおの打の約1000個である。Fig. 


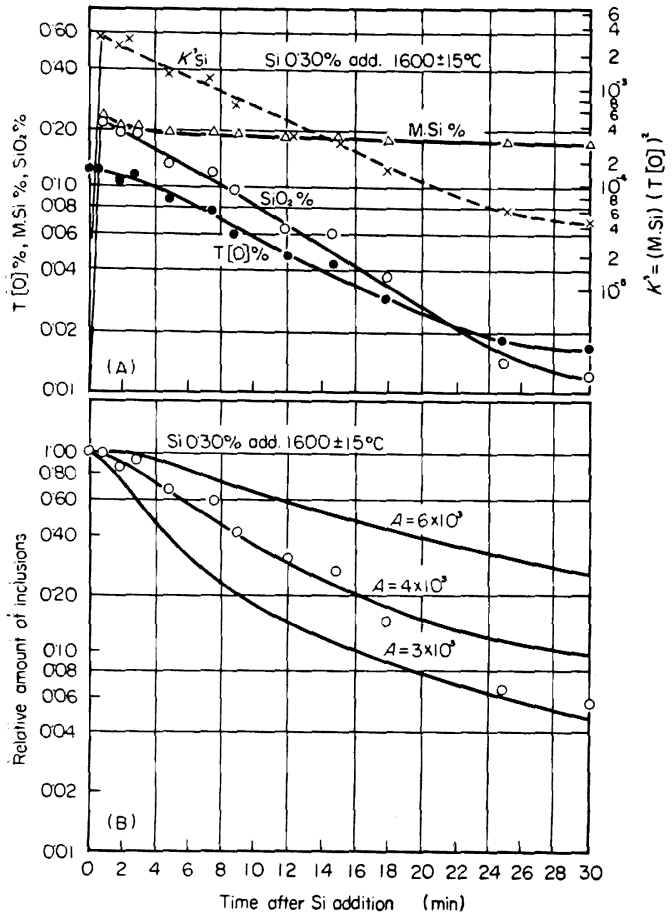

Fig. 9(A), (B). Run of $\mathrm{Si}$ deoxidation in tranquil steel bath at $1600^{\circ} \mathrm{C}$.

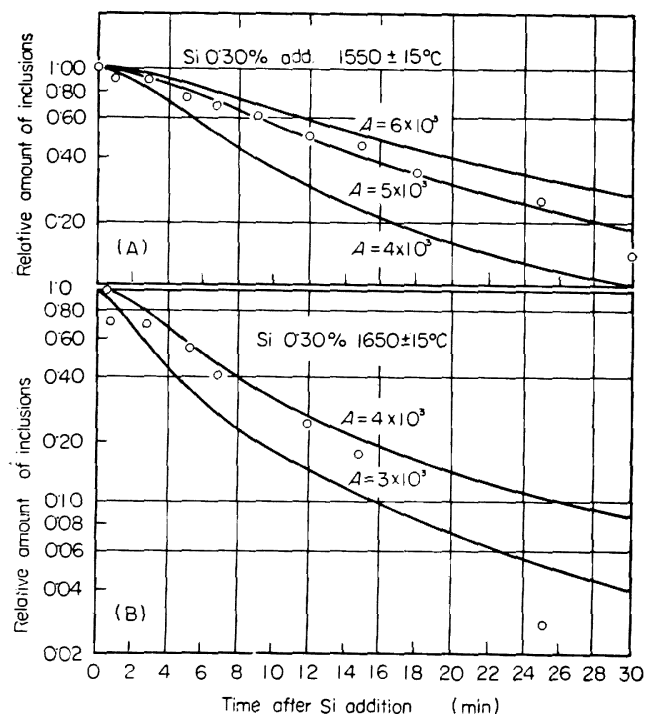

Fig. 10 (A), (B). Run of $\mathrm{Si}$ deoxidations in tranquil steel bath at $1550^{\circ} \mathrm{C}$ and at $1650^{\circ} \mathrm{C}$.

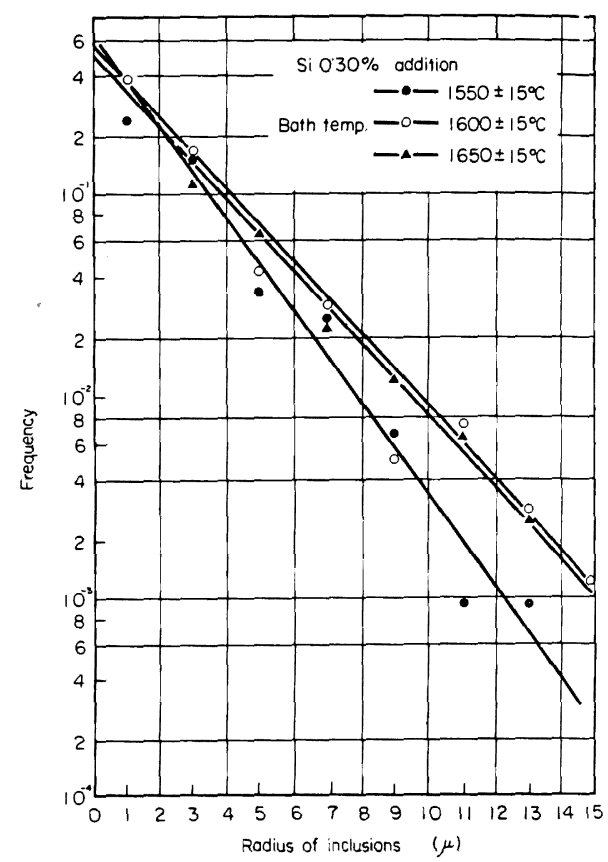

Fig. 11. Distribution of the size of $\mathrm{SiO}_{2}$ inclusion.

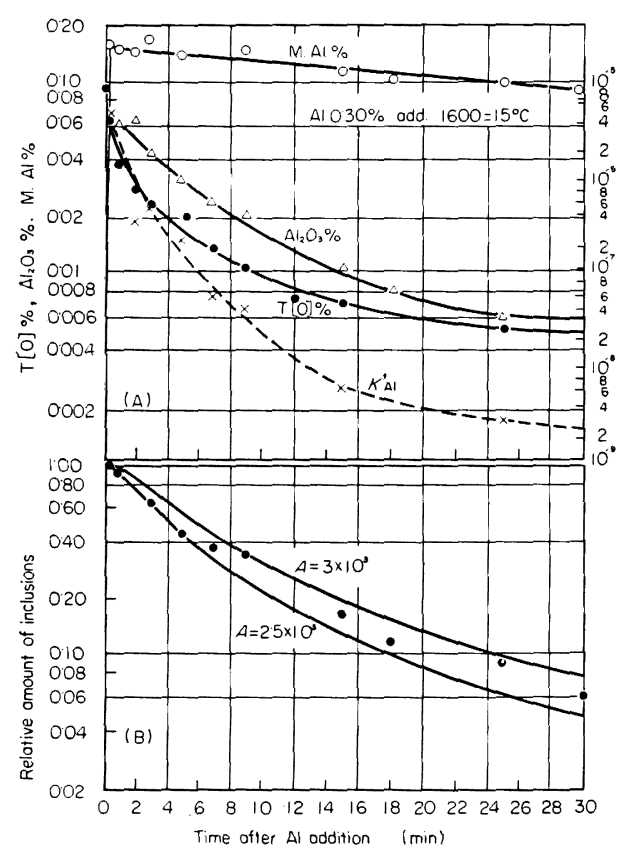

Fig. 12(A), (B). Run of Al deoxidation in tranquil steel bath at $1600^{\circ} \mathrm{C}$. 
II 和 $1550^{\circ} \mathrm{C}$ では $A=5 \times 10^{3}, 1600^{\circ} \mathrm{C}, 1650^{\circ} \mathrm{C}$ で はおのおの $A=3.9 \times 10^{3}$ であり, 1 次介在物の浮上曲 線少ら推定した粒度分布係数とよく一致した。

$3 \cdot 2 \cdot 3$ アルミニウム脱酸20)

$\mathrm{Si}$ 脱酸上全く同様な手法で $\mathrm{Al} 0.3 \%$ を $1600^{\circ} \mathrm{C}$ の

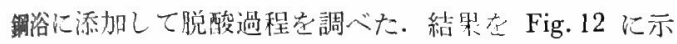
した。1次介在物として酸法による $\mathrm{Al}_{2} \mathrm{O}_{3}$ は $\mathrm{T}[\mathrm{O}]$ の 約 2 倍でかり，よつて 1 次介在物としてよい. $0.5 \mathrm{~min}$

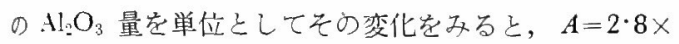
$10^{3}$ 程度の浮上曲線に乗つている. そこで $0.5 \mathrm{~min} の$ 試 料らヨードアルコール法によつて残洫抽出し，その粒

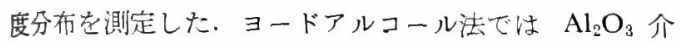
在物に含まれている少量の $\mathrm{FeO}$ も抽出できるから溶鋼 に存在していたままの形状を抽出でき，物理的浮上が介 在物の形状に依存する点を考虑した. 抽出した $\mathrm{Al}_{2} \mathrm{O}_{3}$ 介 在物注不定形て，どの程度の球とみなすかに注問題があ つたが，顕微鏡写真(Photo. 4) 上で 2 軸平均半径 ${ }^{26}$ ) ([短 軸烽十長軸径了/4) 起測定し, 粒度分布係数を決定した。 したがつて多少の誤差を予想したが， $A=2 \cdot 8 \times 10^{3}$ であ り浮上曲線から推定される粒度分布倸数とよく一致した (Fig. 13).

\section{$3 \cdot 2 \cdot 4$ マンガンとシリコンによる共同脱酸}

Fig. 14(A)，(B)にMn 0.5\% と Si $0.3 \%$ による 共同脱酸過程寺した， $\mathrm{Si}$ 脱酸と異なり， $\mathrm{MnO}-\mathrm{SiO}_{2}$ 系介在物法㠜集性がよいため, 脱酸直後の $\mathrm{T}[\mathrm{O}]$ の減 少が大きい. 1 次介在物量は HILty, CRAFt の Mn-Si 一手平平衡索参照し, 溶解酸素を $0.008 \%$ とて, $\mathrm{T}[\mathrm{O}]$ との差を1次介在物の酸素量とした. MnとSiによる共 同脱酸では脱酸直後の凝集が著しく, T $[\mathrm{O}]$ の減少速

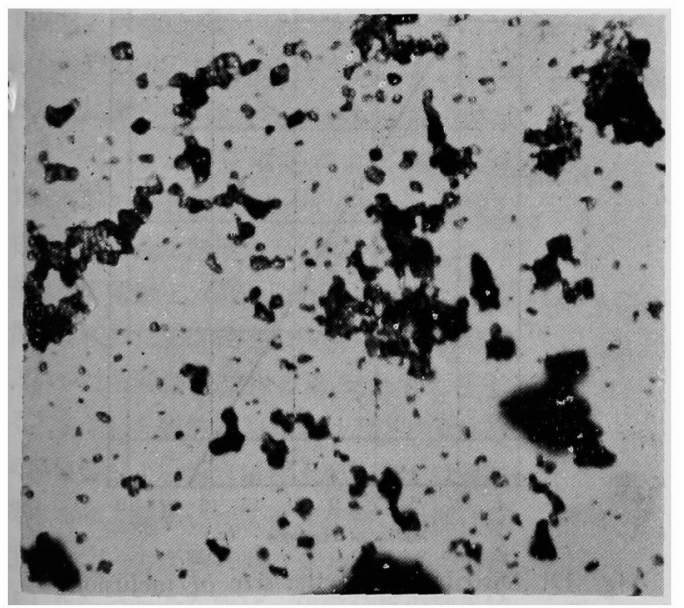

Photo. 4. Inclusion observed at $0.5 \mathrm{~min}$ after 0.3 Al additions. $\times 600(2 / 3)$

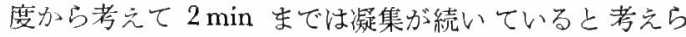
れる。

一方（15）式では浮上途中における凝集老仮定してい ない、そこで $2 \min$ の 1 次介在物を基準としてその浮

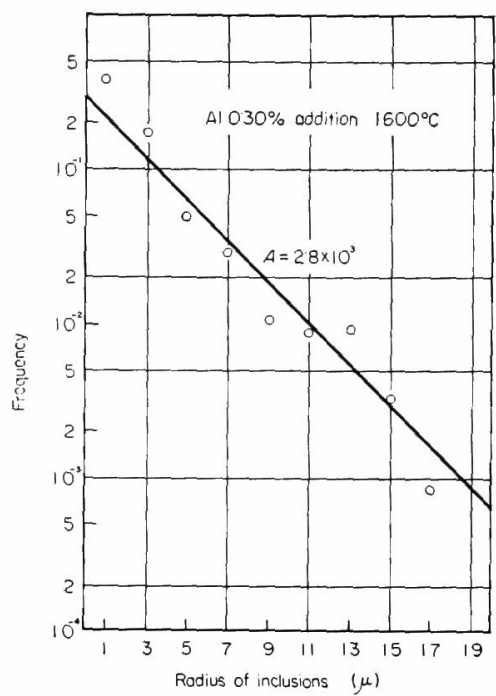

Fig. 13. Distribution of the size of $\mathrm{Al}_{2} \mathrm{O}_{3}$ inclusion.

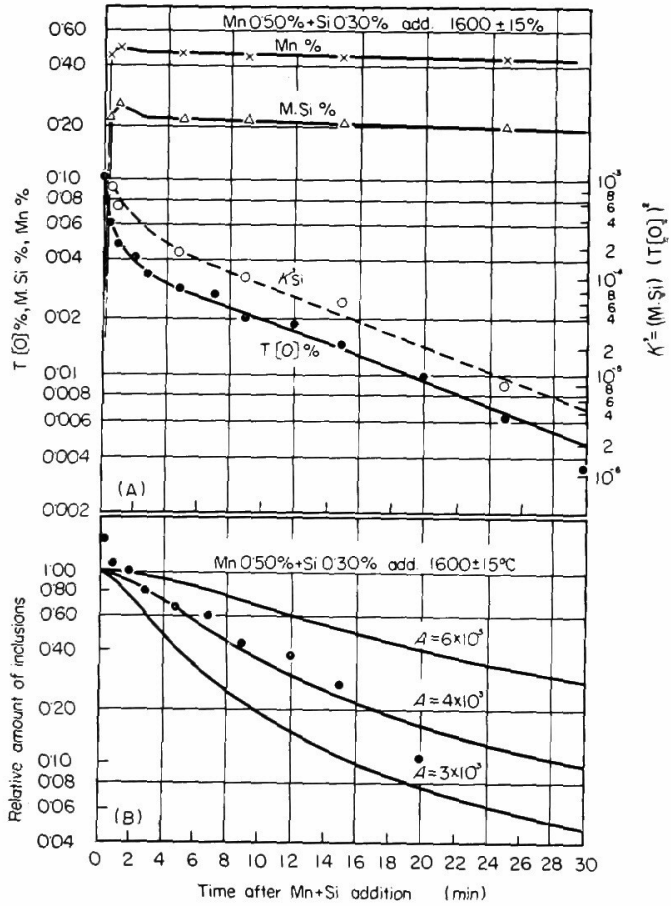

Fig. 14(A), (B). Run of Mn and Si complexdeoxidation. 


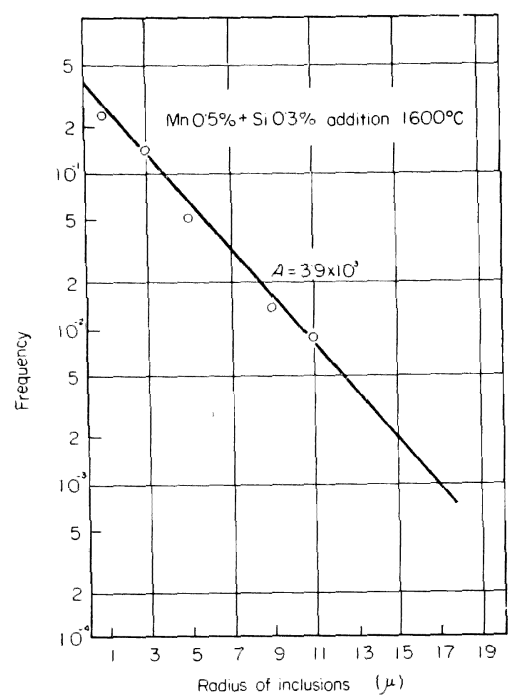

Fig. 15. Distribution of the size of inclusions produced by $\mathrm{Mn}$ and Si complexdeoxidation.

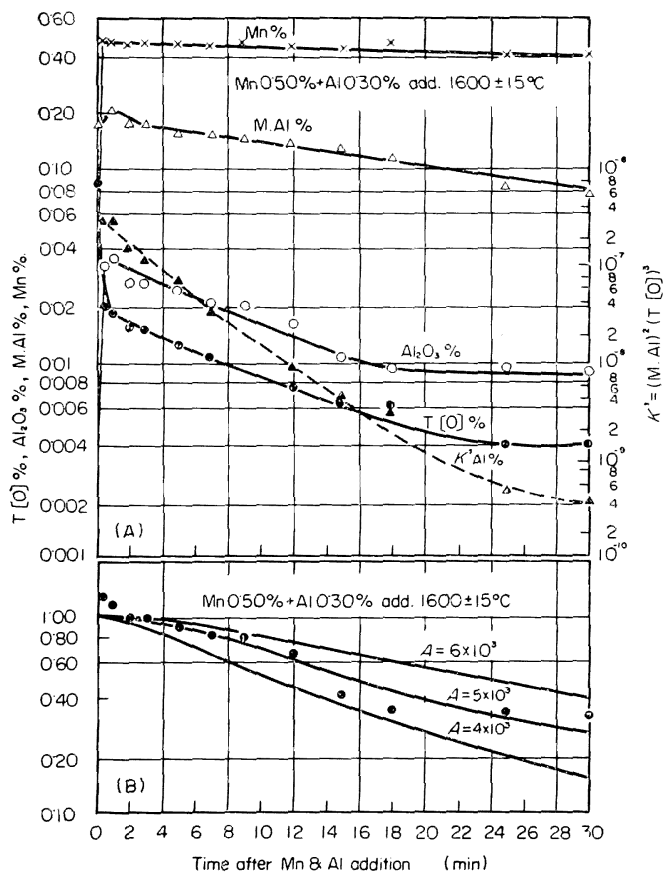

Fig. 16( A), ( B). Run of $\mathrm{Mn}$ and $\mathrm{Al}$ complexdeoxidation in tranquil steel bath.

上傾向を示した。同時に $A=3 \times 10^{3}, 4 \times 10^{3}$, における $\mathrm{SiO}_{2}$ 介在物の浮上速度を示した. 四から脱酸 $2 \mathrm{~min}$ か ら $A=4 \cdot 1 \times 10^{3}$ 程度の浮上速度と考无られる。そこで 脱酸 $2 \mathrm{~min}$ の粒度分布它測定したところ $A=3.9 \times 10^{3}$ となり比較的くよ一致した(Fig. 15).
$3 \cdot 2 \cdot 5$ マンガンとアルミニウムによる共同脱酸21)

Fig. 16(A)，(B) に Mn 0.5\% と Al 0.3\% による共 同脱酸遇程を寺した. Al 脱酸と暴なり，脱酸0.5 minま! てに T[O] の急湤な減少があり，鹠找浴の場合と同粎 凝集性の上、、 $\mathrm{MnO}-\mathrm{Al}_{2} \mathrm{O}_{3}$ 系介在物の浮上によると考 えられら。この1次介在物が浮上した後は，M.Alから 考えて, 比䛎的形状の小さな $\mathrm{Al}_{2} \mathrm{O}_{3}$ が徐々に浮上する。 $\mathrm{T}[\mathrm{O}]$ の約 2 倍が酸法による $\mathrm{Al}_{2} \mathrm{O}_{3}$ 量と一致している。 試料の影微鏡観察から㠜集性の上い $\mathrm{MnO}-\mathrm{Al}_{2} \mathrm{O}_{3}$ 系介在 物は $2 \mathrm{~min}$ まて存在し，支た $\mathrm{T}[\mathrm{O}]$ も， $\mathrm{Al}_{2} \mathrm{O}_{3}$ も2 $\min$ 以徭よりも減少速度が速い（15)式は既述の上おり

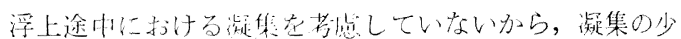
ない $2 \mathrm{~min}$ 以後につい、理唡浮上速度式在適用与る。そ こで脱酸 2 min の $\mathrm{Al}_{2} \mathrm{O}_{3}$ を笚位としてとの後の浮上傾 向上，(15)式に上る浮上曲線を示した。Fig. 16 から $\mathrm{A}$ $=5 \times 10^{3}$ の浮上曲線に想つていると判断される. 一方脱 酸後 $2 \min の$ 試料からヨードアルコール法に上る残渣抽

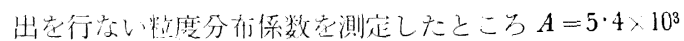
であつた（Fig，17)。アルミニウム脱酸の場合と同様 2 軸 平均半径の測茫には，介任物の形状が不定であり誤差が 生じた上考えられるな，比較的よい一致が得られた。

3.2.6 マンガンレシリコンとアルミニウムによる共 同脱酸20广

Fig. 18 に代表例として Mn 0.5\%， Si 0.30\%，Al $0.30 \%$ を同㭙に $1600 \mathrm{C}$ の鈰浴に添加した場合の脱酸

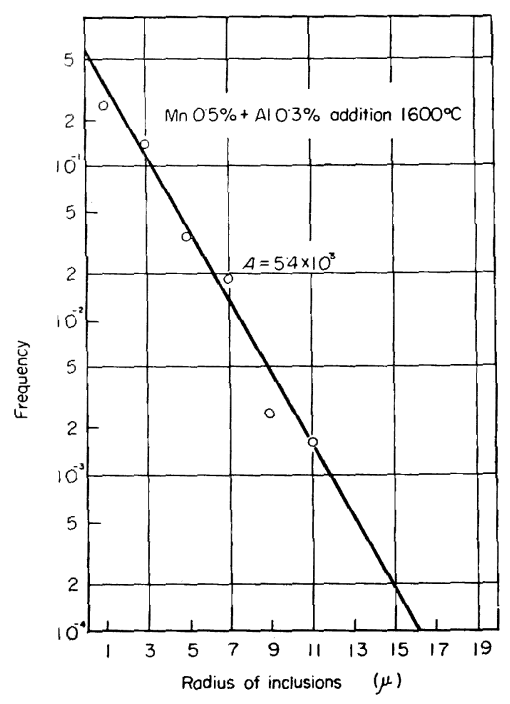

Fig. 17. Distribution of the size of inclusions produced by $\mathrm{Mn}$ and $\mathrm{Al}$ complexdeoxidation. 


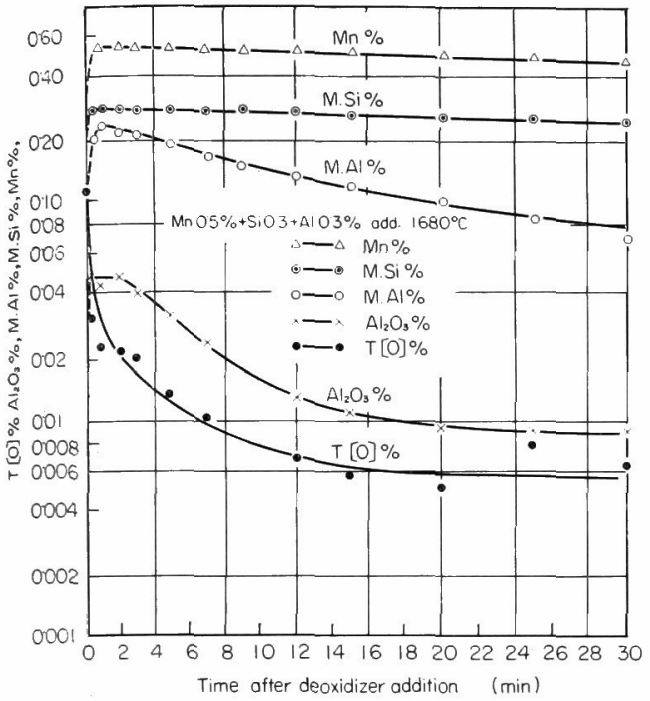

Fig. 18. Run of $\mathrm{Mn}, \mathrm{Si}$ and $\mathrm{Al}$ complex deoxidation.

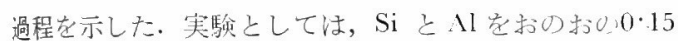
$\%, 0.30 \%, 0.60 \%$ 引変元，Si 量を一定とした場台の Al 量による影留，Al 量を一定とした罫合のSi 量によ ‘る影響を $1600^{\circ} \mathrm{C}$ の鋼溶て調べ，また脱酸剂涯加量を一 定上乙, 鋼浴温度を $1550^{\circ} \mathrm{C}, 1600^{\circ} \mathrm{C} ， 1650 \mathrm{C}$ に変え て、鋼浴温度による影智を調へた。 Fig. 18 から共同脱

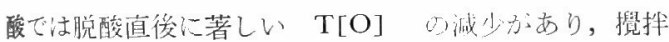

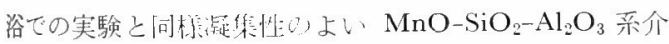
在物の急速な浮上によるものである.マンガンとシリコ ン京よびマンガンとアルミニウムによる共同脱酸の場 合と同様脱酸後 $0.5 \sim 2$ min $の \mathrm{Al}_{2} \mathrm{O}_{3}$ 量老基準と乙て: その後の $\mathrm{Al}_{2} \mathrm{O}_{3}$ 量変化を Fig. 19 に示した。 同時に $\mathrm{Al}$ 添加量, $\mathrm{Si}$ 添加量, 抢よび銅浴温度による影翼をも示 した. Fig. 19 加ら Si 添加量, およし $\mathrm{Al}$ 添加量によらす $A=3.5 \times 10^{3}$ の浮上曲線 泟つている、鋼浴温度による影留では $1650^{\circ} \mathrm{C}$ の場合のみ $A=4.5 \times 10^{3}$ の浮上 曲線に近い浮上速度を有している。この結 果は $\mathrm{Al}$ 脱酸と Mn と $\mathrm{Al}$ こよる共同脱 酸を比較した場分後者の粒度分布係数が小 さかったと同様な理由によると考えら行 る。专なわち脱酸初期における1次介在物 の㠜集性がよい場合注上浮上途中における凝 集もあり，凝集した 1 次介在物は讯速に浮 上する. 一方脱酸初期 ( $2 \mathrm{~min}$ ) までに浮 上しなかつた介在物は，化学分析の結果純 䊉な $\mathrm{Al}_{2} \mathrm{O}_{3}$ であるため形状は小さく，粒度
分布係数は大きいむ, 与浮上速度は遅くなる。実際 $1600^{\circ} \mathrm{C}$ と $1650^{\circ} \mathrm{C}$ の場公以ついた $\mathrm{T}[\mathrm{O}]$ 孝比較吉ると，1650 C の場合は脱酸直後の $\mathrm{T}[\mathrm{O}]$ の減少量が大きいた的， 実験の時間内では $1650^{\circ} \mathrm{C}$ の T[O] が低い。さ 1650 C. 葆除いては $A=3.5 \times 10^{3}, 1650^{\circ} \mathrm{C}$ で $A=4.5 \times 10^{3}$ であるから，1600 C C $1650^{\circ} \mathrm{C}$ の場合について脱酸 2 minの試料をヨードアルコール法で残椬抽出し, (Photo. 5 ）粒度分们老測定し，基準化して Fig. 20 に示した。 その結果 $1600^{\circ} \mathrm{C}$ の場分か $A=3.6 \times 10^{3}, 1650^{\circ} \mathrm{C}$ の場 合 $A=4.5 \times 10^{3}$ ○精度分布定示し，打の沶の1次介在

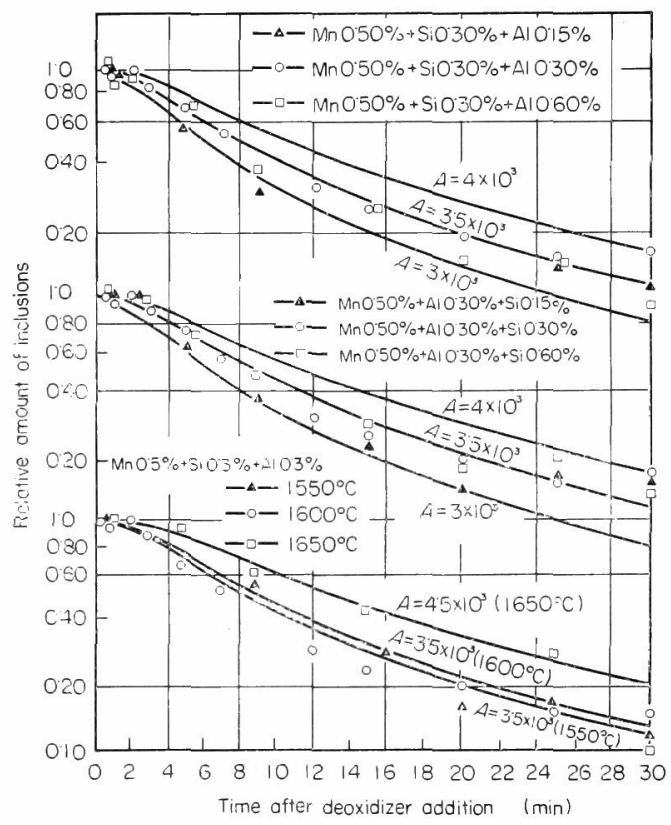

Fig. 19. Rate of rise of inclusions produced by $\mathrm{Mn}, \mathrm{Si}$ and $\mathrm{Al}$ deoxidation.

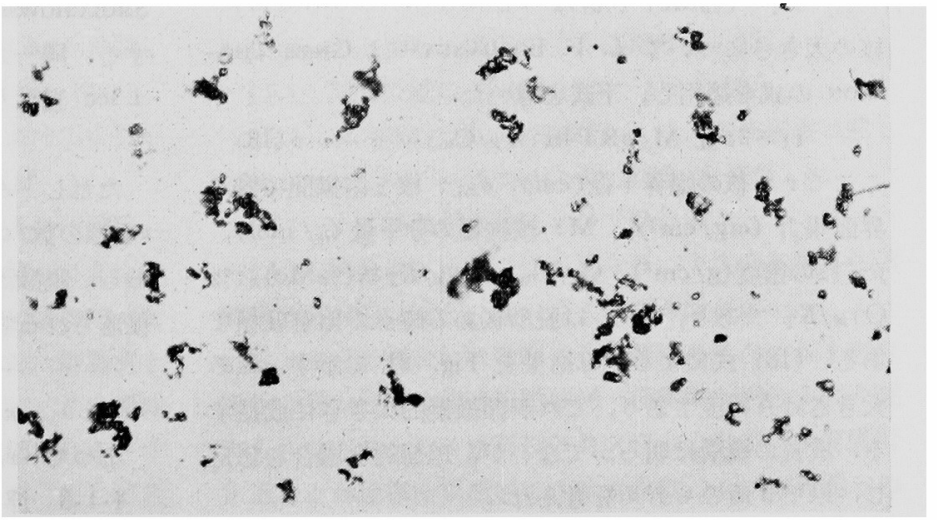

Photo. 5. Inclusion observed at $2 \mathrm{~min}$ after $0.5 \% \mathrm{Mn} 0.3 \% \mathrm{Si}$ and $0.3 \% \mathrm{Al}$ deoxidation. $\times 600(2 / 3)$ 


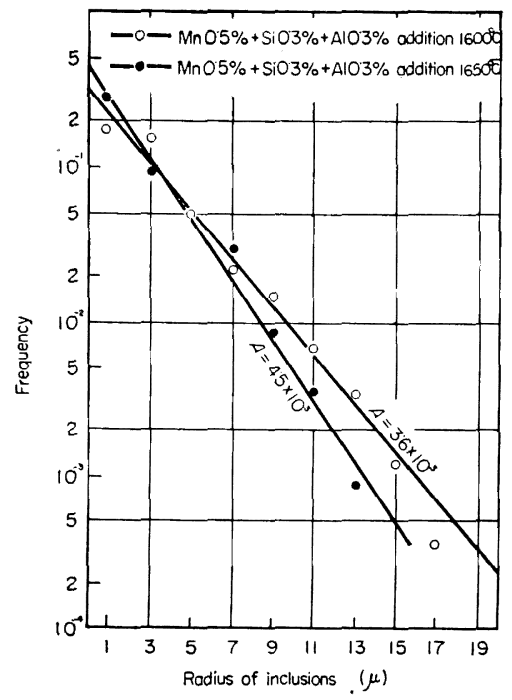

Fig. 20. Distribution of the size of $\mathrm{Al}_{2} \mathrm{O}_{3}$ inclusions produced by $\mathrm{Mn}, \mathrm{Si}$ and $\mathrm{Al}$ complexdeoxidations.

物の浮上傾向から推定される粒度分布と一致した。

\section{4. 考察}

\section{$4 \cdot 1$ 脱酸反応における核の生成と成長}

脱酸剂が酸素を含む鋼浴に添加され 1 次介在物が生成 する過程から考察を始的ると，まず核が生成し，次いで これが顥微鏡的大きさに成長する，この生成と成長は極 めて短時間に行なわれることは実験で証明してきたが， 以下理論的に証明寸る.溶鋼の酸素々脱酸元素は一般的 に下記の脱酸反応を行なう。

$$
n[\mathrm{Me}]+m[\mathrm{O}] \rightleftarrows\left(\mathrm{Me}_{n} \mathrm{O}_{m}\right)
$$

脱酸生成物が純粋な場合は $a_{\mathrm{Me}_{n} \mathrm{O}_{m}}=1$ であるから，

$$
K_{\mathrm{T}}=(\% \mathrm{Me})^{n}(\% \mathrm{O})^{m}
$$

核の大きさについて L. V. BogDANDY ${ }^{22}$ 沫 GiBbs-THOMSON の式を適用し，下式を導いた。

$$
\mathrm{r}_{k}=2 \sigma \mathrm{SL} \cdot \mathrm{M} / \rho \mathrm{RT} \ln \left(\mathrm{C}_{\mathrm{T}} / \mathrm{C}_{\infty}\right) \cdot
$$

ここて $\mathrm{r}$ ：核の臨界半径 $(\mathrm{cm}), \sigma_{\mathrm{SL}}$ ：核と溶鋼間に働く 界面張力 $\left(\mathrm{erg} / \mathrm{cm}^{2}\right), \mathrm{M}$ : 核物質の分子量 $(\mathrm{g} / \mathrm{mol})$, $\rho$ : 核の密度 $\left(\mathrm{g} / \mathrm{cm}^{3}\right), \mathrm{C}_{\mathrm{T}} / \mathrm{C}_{\infty}=K_{\mathrm{T} / a} / K_{\mathrm{T}} \equiv(\% \mathrm{Me})_{n}(\%$ O) $m / K_{\mathrm{T}}$ であり， $K_{\mathrm{T}}^{\prime} a$ は脱酸後ある時点の溶解度積て ある. (18) 式による計算結果を Fig. 21 に示す. 核の 大きさは $\mathrm{A}$ 程度であり，これが顕微鏡的大きさに成壴す る.成長の機構は明らなでないが，理想的な場合を想定 し，以下 3 種のモデルを考えた。

$4 \cdot 1 \cdot 1$ 拡散による成長

FICK の第 2 法則を極座標に展開し；半径 $\mathrm{r}$ の椇に介

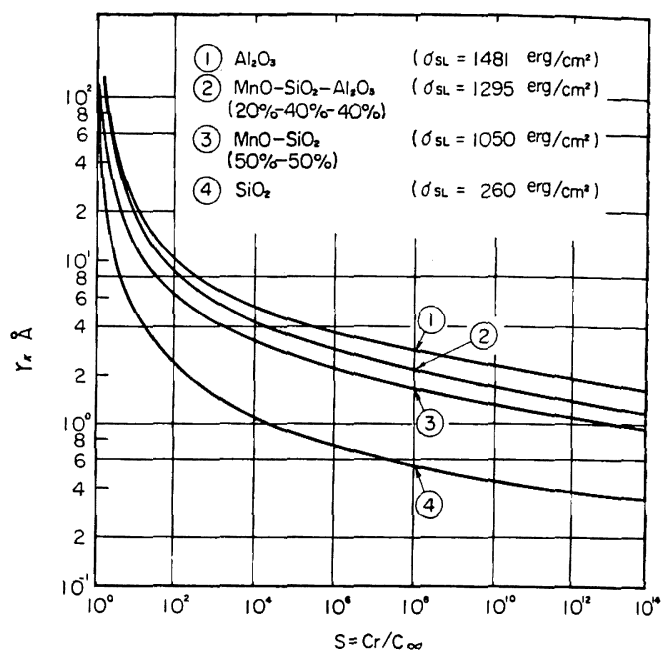

Fig. 21. Relation between nucleus radius and degree of supersaturation.

在物構成原子が拡散するとすれば，拡散原子数を $n$ とし $\tau$

$$
d n / d t=4 \pi D \mathrm{r}_{\mathrm{t}}\left(n_{\mathrm{O}}-n_{\mathrm{eq}}\right)
$$

$D$ : 拡散定数 $\left(\mathrm{cm}^{2} / \mathrm{sec}\right), \mathrm{r}_{\mathrm{t}}$ ：時間 $\mathrm{t}$ における半径, 体 積成長速度は，

$$
d\left(4 \pi \mathrm{r}_{\mathrm{t}}^{3} / 3\right) / d \mathrm{t}=4 \pi D \mathrm{r}_{\mathrm{t}}\left(\mathrm{V} / N_{\mathrm{o}}\right)\left(n_{\mathrm{o}}-n_{\mathrm{eq}}\right)
$$

$N_{\mathrm{o}}$ : Avogadro number, $\mathrm{V}$ : molar volume, $n_{\mathrm{o}}$ : 拡 散原子の濃度（個 $/ \mathrm{cm}^{3}$ ), $n_{\mathrm{eq}}$ ：平衡まで反応したときの 拡散原子浱度 (個 $\left./ \mathrm{cm}^{3}\right)$ ，(20) 積分すると，

$$
\mathrm{r}_{\mathrm{t}}{ }^{2}=\mathrm{r}_{k}{ }^{2}+2 D \mathrm{~V}\left(\mathrm{C}_{\mathrm{o}}-\mathrm{C}_{\mathrm{eq}}\right) \mathrm{t}
$$

$\mathrm{C}_{o}, \mathrm{C}_{e q}$ 恃間 $\mathrm{t}=0$ および平衡後の拡散原子濃度 $\left(\mathrm{mol} / \mathrm{cm}^{3}\right)$

\section{$4 \cdot 1 \cdot 2$ 核同志の衝突による成長}

核はその大きさから colloid 粒子とみなせるから， SMOLCHOWSKI ${ }^{23)}$ の colloid の㠜集に関する理諭を適用 する，同一大きさの核が拡散によつて衝突する回数は， $1 \mathrm{sec}$ 当たり

$$
Z=4 k \mathrm{~T} n^{2} / 3 \eta \equiv A n^{2}
$$

$$
\text { ただし } A \equiv 4 k \mathrm{~T} / 3 \eta
$$

$n$ : 㭶の数 $/ \mathrm{cm}^{3}, \eta$ : 溶鋼の粘性, $k$ : Boltzman 定数で ある・脱酸添加時の攪拌など物理的攪拌によつて衝突が 促進される場合は㩭拌効果を $\alpha \geqq 1$ として,

$$
\begin{aligned}
& -d n_{\mathrm{t}} / d \mathrm{t}=\alpha A n_{\mathrm{t}}{ }^{2} \text { であるから } \\
& n_{\mathrm{t}}=n_{\mathrm{o}} /\left(1+\alpha A n_{\mathrm{o}}\right) \\
& \text { よつて } \mathrm{r}_{\mathrm{t}}{ }^{3}=\mathrm{r}_{k}{ }^{2}\left(1+\alpha A n_{\mathrm{ot}}\right)
\end{aligned}
$$

\section{$4 \cdot 1 \cdot 3$ 浮上途中における凝集成長}

粒子半径が $10^{-4} \mathrm{~cm}$ 以上ではストークス法則による 浮上を行なうと考えられる，特に大きく成長した粒子に 


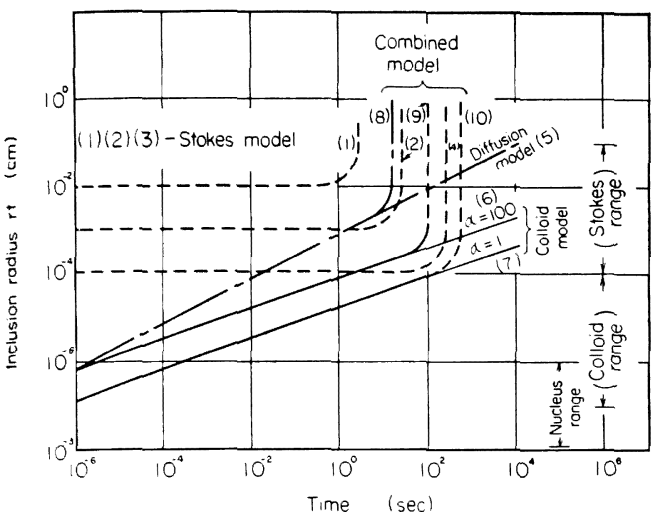

Fig. 22. Growth of inclusions according to three typical models.

かてはここれが浮上し，他の精子が静止している場合 の浮上途中江扮ける渴集莙考える。

$$
4-\mathrm{r}_{\mathrm{t}}^{3} d \mathrm{r}=\pi \mathrm{r}_{\mathrm{t}}^{2} \mathrm{~V}_{\mathrm{t}} \alpha d \mathrm{t}
$$

$\alpha$ : Volume of inclusion $/ 1 \mathrm{~cm}^{3}$ Metal, $V_{t}=2 \mathrm{gr}^{2}$

$\left(o_{\mathrm{Fe}}-o_{\mathrm{in}}\right) / 9 \mathrm{r}$ であるから

$$
\mathrm{r}_{\mathrm{t}}=\mathrm{r}_{\mathrm{i}} /\left[\mathrm{l}-\mathrm{g}\left(\rho_{\mathrm{Fe}}-\rho_{\mathrm{in}}\right) \mathrm{r}_{\mathrm{w}} \alpha \mathrm{t} / 18 r_{\mathrm{i}}\right]
$$

以上 3 種のモデルを $\mathrm{C}_{1},-\mathrm{C}_{\mathrm{eq}}=0 \cdot 10_{0} \mathrm{O}$ 上して, Si 脱 酸につれ、計算した結果左 Fig. 22 に示した。実降に どのモデル汇よつて成長するか確証がないか，寒䮖結 果上一致している。これらの結果众在物が㩆嘚鏡的犬き

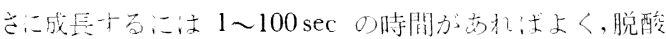
直後に脱酸后応は完了寸ることが説明てきた。

\section{2 高周波攪找浴における 1 次介在物の浮上分離機構}

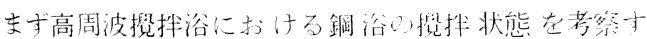

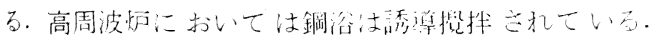

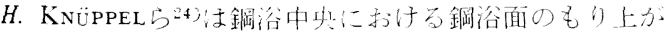
り高之 $\mathrm{h}(\mathrm{cm})$ は下式に侹うこ上を確恐している。

$$
\mathrm{h}=31 \cdot 6(\mu / R \mathrm{f})^{1 \cdot 2 \mathrm{Ni} / \mathrm{F} \rho_{\mathrm{Fe}}}
$$

ここf: 周波数 $(\mathrm{c} / \mathrm{sec}), \rho_{\mathrm{Fe}}$ ：鎆の密度 $\left(\mathrm{kg} / \mathrm{cm}^{3}\right)$, $\mu$ : 溶鋼の透磁率， $\mathrm{R}$ ：溶鋼の比抵抗 $\left(\Omega \cdot \mathrm{cm} \cdot 10^{-4}\right)$,

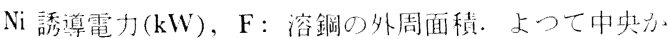
ら外周江向力口て平均流速 $v(\mathrm{~cm} / \mathrm{sec})$ は

$$
\bar{v}=(1 / 2)(2 g h)^{1 / 2} .
$$

本実娩で注 $\mathrm{f}=30 \times 10^{3}(\mathrm{C} / \mathrm{sec}), \mathrm{Ni} \approx 4 \mathrm{~kW}$ である。 よつて $\bar{\tau}=11 \cdot 9(\mathrm{~cm} / \mathrm{sec}) .16 \mathrm{~mm}$ カメラによつて 測定したにころ $v_{\mathrm{ob}}=8 \cdot 7(\mathrm{~cm} / \mathrm{sec})$ ですつた計算值と の差はあるが本実験の鋼浴の掜拌度は大きいここの掜拌 浴でストークス法則による物理的浮上が予想されるとす れば鋼浴表面上における表面流机からである。そこで表 面流れからストークス法則による浮上を仮定した場合の 理論的浮上速度を導いてみたＥ．S. MACKLIN ${ }^{25) に よ れ ~}$
ば高周波臔找浴は，その面で摩擦のない層流をしてい る。この層流の表面から」lの染さまでに存在する介在 物が中央から外周へ流れる間にストークス法則による浮 上を行ない鋼治か、除去されるとする。介在物裖度を $\mathrm{C}$ とすれば

$$
-d \mathrm{C} / d \mathrm{t}=(d \mathrm{M} / d A)(d A / d \mathrm{t}) / \rho \mathrm{V}
$$

ここで $(d \mathrm{M} / d A)$ : 単位表面からの浮上量, $(d A / d \mathrm{t})$ : 表面の湧き出し速度で， $d A / d \mathrm{t}=2 \pi \mathrm{RV}_{\mathrm{R}}$ （R：ルツボ半 径, $\mathrm{V}_{\mathrm{R}}$ ：流凁）である。流体が 中心から外周にいたる までの時問 $\mathrm{t}^{\prime}$ は，連続の条件 $2 \pi \xi \mathrm{V}_{\xi}=2 \pi \mathrm{RV} \mathrm{V}_{\mathrm{R}}$ 觉考虑 する上

$$
\mathrm{t}^{\prime}=\int_{0}^{\mathrm{R}} d \xi / \mathrm{V}_{\xi}=\int_{0}^{\mathrm{R}}\left(\xi / \mathrm{V}_{\mathrm{R}} \mathrm{R}\right) d \xi=\mathrm{R} / 2 \mathrm{~V}_{\mathrm{R}} \cdots
$$

(30) 上ストークス法則による浮上速度 $v_{\mathrm{S}}$ を考虑寸れば $d \mathrm{M} / d A=J l \rho \mathrm{C}=v_{\mathrm{S}} \mathrm{t}^{\prime} \rho \mathrm{C}=v_{\mathrm{S}} \mathrm{R} \rho \mathrm{C} / 2 \mathrm{~V}_{\mathrm{R}}$

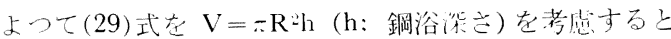
$-d \mathrm{C} / d \mathrm{t}=\left(v_{\mathrm{S}} R \rho \mathrm{C} / 2 \mathrm{~V}_{\mathrm{R}}\right) \cdot 2 \pi \mathrm{RV}_{\mathrm{R}} \cdot / \rho \mathrm{V}=v_{\mathrm{S}} \mathrm{C} / \mathrm{h}$

$1600 \mathrm{C}$ の錩浴厂，平均半径 $10 \mu$ の $\mathrm{SiO}_{2}$ 介在物を含 生鋼浴力らの浮上速度は(32) 式上り

$$
-d \mathrm{C} / d \mathrm{t}=1 \cdot 09 \times 10^{-1} \mathrm{C}=k \mathrm{C}
$$

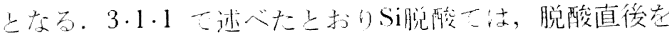
除け㞽平栏半径 $10 \mu$ 以下であるが $k=0.43\left(\mathrm{~min}^{-1}\right)$ $\left(1600^{\circ} \mathrm{C}\right)$ でり，(33)式ては $k=0 \cdot 109\left(\mathrm{~min}^{-1}\right)(1600$ C . 一あるから，理諭的浮上速度より実際は速い。交た (32) 式上り䤱浴深さが h/2 となれば浮上分䜅係数は 2 倍となるは寸てある。同一ルツボで $5 \mathrm{~kg}$ と $2.5 \mathrm{~kg} の$

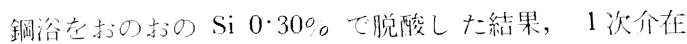
物の浮上速度洞一七市つた。以上の結果脱酸直後芯除 く之，高周波睍找浴では物理的な浮上によつて介在物が 浮上寸るのさはないこ上が明らかであるら．以上の結果 老列挙してみると，鼬拌浴の介在物浮上に関し

（1）浮上分離は $\mathrm{C}=\mathrm{C}_{\mathrm{o}} \exp (-k \mathrm{t})$ に良う.

(2) $\mathrm{Si}$ 脱酸の浮上分離係数 $k$ は, 鋼浴温度に闒し ARRHENIUS の式 $k=\mathrm{A} \exp (-\mathrm{Q} / \mathrm{RT})$ を満足した.

(3) $k$ 注脱酸戍の量によつて異なる.

（4） $k$ はルツボによつて異なり，1 次介在物上化学 的親和力が強いほど，その浮上分嶊速度が速い。

以上の点を緿公して判断すると掜拌浴における1次介 在物の浮上分離の律速段階は同一掜找度の場台 1 次介在 物とルツボ材もしくは表面スラツグとの吸着反応速度で ある.この際鋼浴の缷挷は 1 次介在物のルツボ表面への 移動速度を促進する.したがつて攪拌度が小さい場合は 1 次介在物の浮上速度は遅くなる.実際異なつた高周波 
Table 1. Separation rate constant $\left(\min ^{-1}\right)$ obtained at different deoxidations of steel bath stirred by high-frequency-induction.

\begin{tabular}{|c|c|c|c|c|c|c|}
\hline \multirow{2}{*}{ Deoxidation } & \multicolumn{3}{|c|}{$0.3 \%$} & $0 \cdot 15 \%$ & $0.30 \%$ & $0.60 \%$ \\
\hline & $1550^{\circ} \mathrm{C}$ & $1600^{\circ} \mathrm{C}$ & $1650^{\circ} \mathrm{C}$ & \multicolumn{3}{|c|}{$1600^{\circ} \mathrm{C}$} \\
\hline $\begin{array}{l}\mathrm{Si} \\
\mathrm{Al}\end{array}$ & $\begin{array}{l}0 \cdot 30 \\
0 \cdot 33\end{array}$ & $\begin{array}{l}0 \cdot 43 \\
0 \cdot 42\end{array}$ & $\begin{array}{l}0 \cdot 71 \\
0 \cdot 94\end{array}$ & $\begin{array}{l}0 \cdot 8 \\
0 \cdot 63\end{array}$ & $\begin{array}{l}0 \cdot 43 \\
0 \cdot 42\end{array}$ & $\begin{array}{l}0 \cdot 35 \\
0 \cdot 75\end{array}$ \\
\hline $\begin{array}{l}\mathrm{Mn}+\mathrm{Si} \\
\left(1600^{\circ} \mathrm{C}\right)\end{array}$ & \multicolumn{3}{|c|}{$\begin{array}{c}\text { Mn } 0.5 \%+S i \quad 0.3 \% \\
0.63\end{array}$} & \multicolumn{3}{|c|}{$\begin{array}{c}\text { Mn } 1 \%+\mathrm{Si} 0.3 \% \\
0.69\end{array}$} \\
\hline $\begin{array}{l}\mathrm{Mn}+\mathrm{Al} \\
(1600 \mathrm{C})\end{array}$ & \multicolumn{3}{|c|}{$\begin{array}{c}\mathrm{Mn} 0.5 \%+\mathrm{Al} 0.3 \% \\
0.52\end{array}$} & \multicolumn{3}{|c|}{$\begin{array}{c}\mathrm{Mn} 1 \%+\mathrm{Al} 0.3 \% \\
0.63\end{array}$} \\
\hline Temp. & $1550^{\circ} \mathrm{C}$ & $1600^{\circ} \mathrm{C}$ & $1650^{\circ} \mathrm{C}$ & \multicolumn{3}{|c|}{$1600^{\circ} \mathrm{C}$} \\
\hline $\mathrm{Mn}+\mathrm{Si}+\mathrm{Al}$ & \multicolumn{3}{|c|}{$(\mathrm{Mn} 0 \cdot 5 \%+\mathrm{Si} 0 \cdot 3 \%+\mathrm{Al} 0 \cdot 3 \%)$} & \multicolumn{3}{|c|}{$\begin{array}{c}0.62 \\
(\operatorname{Mn} 0.5 \%+ \\
\left.\quad \operatorname{Si}\left\{\begin{array}{l}0.15 \% \times 0.15 \% \\
0.30 \%-0.30 \% \\
0.60 \% \times 0.60 \%\end{array}\right\} \mathrm{Al}\right)\end{array}$} \\
\hline $\begin{array}{ll} & \text { Deoxidation } \\
\text { Crucible } & \\
\end{array}$ & \multicolumn{3}{|c|}{ Si $0 \cdot 3 \%(1600 \mathrm{C})$} & \multicolumn{3}{|c|}{ Al $0.3 \%\left(1600^{\circ} \mathrm{C}\right)$} \\
\hline $\begin{array}{c}\mathrm{SiO}_{2} \\
\mathrm{MgO} \\
\mathrm{Al}_{2} \mathrm{O}_{3} \\
\mathrm{CaO}-\mathrm{CaF}_{2}\end{array}$ & \multicolumn{3}{|c|}{$\begin{array}{r}0 \cdot 42 \\
0 \cdot 43 \\
0 \cdot 59 \\
>0 \cdot 93\end{array}$} & \multicolumn{3}{|c|}{$\begin{array}{l}0.52 \\
0 \cdot 43 \\
0 \cdot 41 \\
>1 \cdot 2\end{array}$} \\
\hline
\end{tabular}

コイルを使用しなとき注，1次介在物の浮上速度が遅く

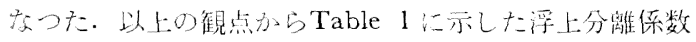

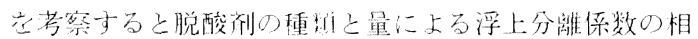

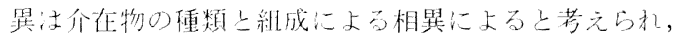

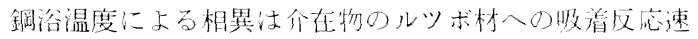
度に対する温度の影管であると理解できる。

\section{$4 \cdot 3$ 静止浴における 1 次介在物の浮上機構}

静止浴に扮ける脱酸過程老，ストークス法則在仮定し た理諭的浮上速度式により解析，㮆討してきた結果，こ の速度式によりよく説明できることがわかなっここで (15)式在導したときに立てた仮定を検討してみる。Fig. 8 :示したT[O]の挙動から定性的てはあるが鋼浴中の

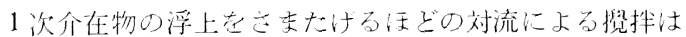
没いと考无られる。次にストークス法則であるが粉体粒

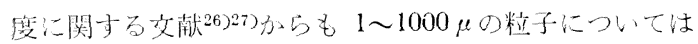
寸へてストークス法則定適用している. 小池 ${ }^{29}$ 涾銀中 混大させた酸化物粒子についても同法則が適用できる としている。最後に浮上塗中における凝集であるか， $\mathrm{Mn}$ 它含主共同脱酸で涚集性のよい $\mathrm{MnO}-\mathrm{SiO}_{2}$ 系あ るい法 $\mathrm{MnO}-\mathrm{Al}_{2} \mathrm{O}_{3}$, 更には $\mathrm{MnO}-\mathrm{SiO}_{2}-\mathrm{Al}_{2} \mathrm{O}_{3}$ 系介在 物が脱酸直後に生成主るため, 浮上途中における凝集が 想定される. 実際にも共同脱酸で脱酸 $0.5 \mathrm{~min}$ の粒度分 布係数を測定してみると，1次介在物の浮上曲線から推
Table 2. Comparison of the distribution of inclusion size among different deoxidations.

\begin{tabular}{|c|c|c|c|}
\hline Deoxidation & $\begin{array}{c}\text { Bath temp. } \\
\text { ( C })\end{array}$ & A* & $A * *$ \\
\hline $\mathrm{Si}$ & $\begin{array}{l}1550 \\
1600 \\
1650\end{array}$ & $\begin{array}{l}5 \cdot 0 \times 10^{3} \\
4 \cdot 0 \times 10^{3} \\
4 \cdot 0 \times 10^{3}\end{array}$ & $\begin{array}{l}5 \cdot 0 \times 10^{3} \\
3 \cdot 9 \times 10^{3} \\
3 \cdot 9 \times 10^{3}\end{array}$ \\
\hline $\mathrm{Al}$ & $\begin{array}{l}1550 \\
1600 \\
1650\end{array}$ & $\begin{array}{l}3 \cdot 0 \times 10^{3} \\
2 \cdot 7 \times 10^{3} \\
3 \cdot 6 \times 10^{3}\end{array}$ & $2 \cdot 8 \times 10^{3}$ \\
\hline $\mathrm{Mn}+\mathrm{Si}$ & 1600 & $4 \cdot 1 \times 10^{3}$ & $3 \cdot 9 \times 10^{3}$ \\
\hline $\mathrm{Mn}+\mathrm{Al}$ & 1600 & $5 \cdot 0 \times 10^{3}$ & $5 \cdot 4 \times 10^{3}$ \\
\hline $\mathrm{Mn}+\mathrm{Si}+\mathrm{Al}$ & $\begin{array}{l}1600 \\
1650\end{array}$ & $\begin{array}{l}3.5 \times 10^{3} \\
4.5 \times 10^{3}\end{array}$ & $\begin{array}{l}3 \cdot 6 \times 10^{3} \\
4 \cdot 6 \times 10^{3}\end{array}$ \\
\hline
\end{tabular}

A* : determined by the rate of rise of incluion

$\mathrm{A}^{* *}$ : determined by measuring of inclusion size

定さ机る值より小さく，大きな介在物を含えでいること ぶわかつた。したがつて（15）式は浮上途中における㠜 集の少ない脱酸直後を除いた時期に適用できる、Table 2 に本実験で得られた粒度分布係数を一括して示した。

\section{4 現場作業への提案}

以上基礎的な研究ではあるが現場の脱酸作業に対し重 要なヒントが与えられている.現場脱酸作業で重要な取 鍋脱酸洅検討され，また十分な注意が払われるべき 
で品ろう・脱酸という点からは，共同脱酸が望ましいの て許される範囲内ン，Si-Mn，Mn-Al，Si-Mn-Alなど の合金脱酸剂の使用が望ましいであるう。专なわら脱酸 初期に就集性のよい1 次介在物の生成が期待てきる。更 飞脱酸剂添加時の鋼浴の鄮拌状態は 1 次介在物の街突に よる凝集機会在左与る点で重要である。出銓の取鍋は 静止浴に近いのて（15）式を利用一れ技鍋に扮ける1 次介在物の浮上過程も計算できる。高さ $3 \mathrm{~m}$ 取鍋につ いて計算した結果，取鍋における1次在物の浮上はほ とえど期待できないことが执かた。また ドルキリングを行なつた場公についても試算したか，介

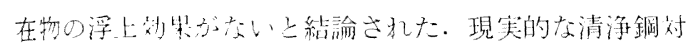
策として著者は取鍋の鋼浴至不活性ガスによつて搜拌与

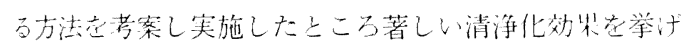
ることができた。この点については他の㙨会に報告寸 ろ.

\section{5. 結}

\section{訔}

高周波掜汼鋼浴とタンマン炬に上る静止錭浴で $\mathrm{Mn}$, $\mathrm{Si}$ ，Al などの慣用脱酸新により脱酸し，脱酸過程在速 度論的立場から解析し，1次介在物の浮上分沟速度定定

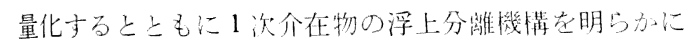
した。

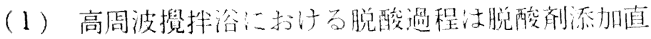
後と大れ以後の時期上て法異なつた浮上過程にしたる。 j.

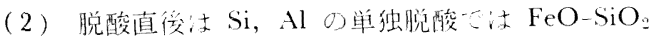

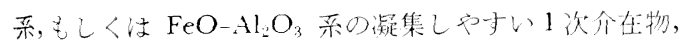
$\mathrm{Mn}$ 在含毛共同脱酸で法 $\mathrm{MnO}-\mathrm{SiO}_{2}$ 系, $\mathrm{MnO}-\mathrm{Al}_{2} \mathrm{O}_{3}$ 采，毛しくは $\mathrm{MnO}-\mathrm{SiO}_{2}-\mathrm{N}_{\mathrm{O}}$ 系の㠜集した大型介在

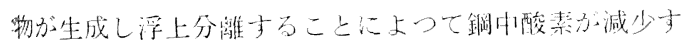
る.

(3) 上記の脱酸直後を除くと, 攽挥治では $\mathrm{C}=\mathrm{C}_{0}$

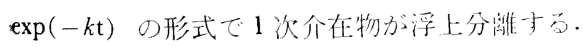

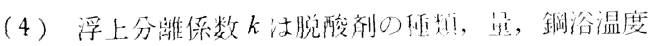
および特にルツボの種頑によつて異なる。

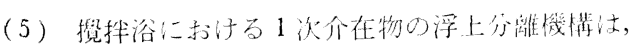
䑫酸剂添加直後を除けば，1次介在物とルツボ朴との呚 着反応である.

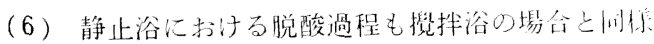

脱酸剂添加直後とそれ以後の時期とで異なつた浮上過程 にしたがう。

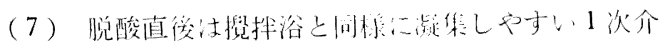
在物が生成し，その浮上によつて錩中酸素が減少与る。

（8）上毁门時期荤除くと，1次介在物はストークス 法則によつて浮上寸る。

（9）したがつて1次介在物の粒度分布倸数方与元ら

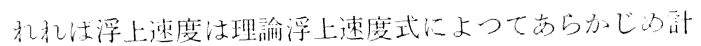
算できる。

（10）取鍋中の鋼浴な上の青此銅浴か51次介在物を 浮上分離させるためには鄮找在与えることが重要であ 子.

\section{文献}

I) W. A. Fischer et al.: Arch. Eisenhüttenw., 28 (1957), p. $601 \sim 9$

2）松下，任野：鉄と銅，47 (1961), p. 168〜170

3) 川和, 他：鉄と銅，50 (1964)， p. 1859 1861

4) 川和, 他: 鉄と鋼, 51 (1965), p. 774 777

$5)$ M.troba et al.: Trans. Nat. Reser. Inst. Metals, 3 (1961) 2, p. 81 92

6) W. A. Fischer et al.: Arch. Eisenhüttenw., 28 (1957), p. 379 382

7 ) 川和, 他: 鉄と錩, 51 (1965), p. 777〜 780

8 ) Tech. Mitt. Krupp., 18 (1960), p. 65 80

9 ) Arch. Eisenhüttenw., 32 (1961) p. 387 390

10) 川和, 他: 鉄と銅, 51 (1965), p. 780 783

11) H. Schenck et al.: Arch. Eisenhüttenw., 31 (1960), p. $567 \sim 569$

12) Mitt. K. Wily. Eisenforsch, 15 (1933), p. 271

13) Trans. A.I.M.E., 188 (1956), p. 425 436

14) Trans. A.I.M.E., 227 (1963), p. 560 562

15) 川和, 他: 鉄と锏, 51 (1965), p. 783 785

16) 川和, 他: 鉄と銅, 52 (1966), p. 528〜 530

17) 川和, 他: 鉄と銅, 52 (1966), p. 531 534

18) J. A. Kitchner et al.: J. Iron Steel Inst., (1955), p. 324

20）川和，他：鉄之鋼，52（1966), p. 1457 1460

21) 川和，他：鉄と鋼，52(1966), p. 1460 1463

22) Arch. Eisenhüttenw., 32 (1961), p. 451 461

23) Physical Chemistry, Moelwyn Hughes, (1961), p. 1213, Pergamor Press

24) Arch. Eisenhüttenw., 33 (1962), p. 729

25) Trans. A.I.M.E., 218 (1960), p. 314

26) 久保輝一郎編，粉体，昭37年，丸並，p. 108

27）川口, 田村：椟度, 昭33年, コロ十社

28）小池：富士製鉄技報，第３缼，1号，p. 36 